Supporting Information for

\title{
Selective Cleavage of Allyl and Propargyl Ethers to Alcohols Catalyzed by $\mathrm{Ti}(\mathrm{O}-\mathrm{i}-\mathrm{Pr})_{4} / \mathrm{MX}_{\mathrm{n}} / \mathrm{Mg}$
}

Mutsumi Ohkobo, Sayaka Mochizuki, Takeshi Sano, Yuuki Kawaguchi and Sentaro Okamoto*

Department of Applied Chemistry, Kanagawa University, 3-27-1 Rokkakubashi, Kanagawa-ku, Yokohama 221-8686, Japan

okamos10@kanagawa-u.ac.jp

Index

Comments

page 2

${ }^{1} \mathrm{H}$ and ${ }^{13} \mathrm{C}$ NMR spectra of allyl- and propargyl ethers 1, 3 and 4, esters 8-10, and bezene derivatives $2 \mathbf{a}$ and $2 \mathbf{b}$. pages 3-48

Compounds

In Figure 1: 3a 3b 3d 3f 3j 3k 4a 4b 4e 4f 4g 4h 4i 4j 4k

In Figure 2: 8910

In Scheme 6: 1-Allyloxymethyl-4-benzyloxybenzene

(4-Benzyloxyphenyl)-methanol

1-Benzyloxy-4-methylbenzene ( ${ }^{1} \mathrm{H}$ NMR)

1-Chloromethyl-4-benzyloxybenzene ( ${ }^{1} \mathrm{H}$ NMR)

In Scheme 1: $\mathbf{2 a}$ and $\mathbf{2 b}$ 
NMR spectra were recorded by use of a solution in $\mathrm{CDCl}_{3}$ at $600 \mathrm{MHz}$ for ${ }^{1} \mathrm{H}$ and $150 \mathrm{MHz}$ for ${ }^{13} \mathrm{C}$, respectively, on JEOL JNM-ECA600 spectrometers. The substrate ethers $\mathbf{1}^{1}{ }^{1} \mathbf{3}^{2} \mathbf{4}^{3}$ and esters 8-10 were prepared from the corresponding alcohol according to conventional reaction conditions and the following purification by column chromatography, ${ }^{5}$ and their NMR spectra are attached in the following pages. The product alcohols which were obtained by the present deallylation and/or depropargylation of ethers 3, 4 or esters 8-10 are the known compounds, many of which are commercially available, and were characterized by comparison of their NMR spectra with those of the corresponding parent alcohols and TLC analysis. The benzene derivatives 2a-d which were obtained from alkyne 1a, 1b, phenylacetylene or 1-hexyne were identical to the authentic samples prepared previously by us. ${ }^{1}$

This file includes NMR spectra of the following compounds:<smiles>C#CCOc1ccc2ccccc2c1</smiles><smiles>C#CCOCCCc1ccccc1</smiles><smiles>C#CCOCCCCOCc1ccccc1</smiles>

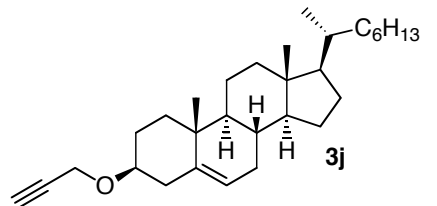<smiles>C=CCOC1C(C2COC(C)(C)O2)OC2OC(C)(C)O[C@H]21</smiles><smiles>C=CCOc1ccc2ccccc2c1</smiles><smiles>C=CCOCCCc1ccccc1</smiles>

$3 k$<smiles>C/C=C/COCCCc1ccccc1</smiles>

$4 \mathrm{e}$<smiles>C=CCOCCCCOCc1ccccc1</smiles>

$4 f$ (E/Z mixture)<smiles>C=CCOCCCCOC(=O)C(C)(C)C</smiles><smiles>C=CCOC1CCC2(C)C3=CCC4C(CCC5(C)C(C(C)CCC)CCC45)C3CC2C1</smiles><smiles>C=CCOCCCCOCCCC</smiles>
$4 \mathrm{~g}$<smiles>C=CCOCCCCC[PH]</smiles><smiles>C=CCO[C@H]1C(C2COC(C)(C)O2)OC2OC(C)(C)O[C@H]21</smiles>
$4 k$<smiles>C=CCOC(=O)OCCCc1ccccc1</smiles><smiles>C=CCOC(=O)OC1C(C2COC(C)(C)O2)OC2OC(C)(N)O[C@H]21</smiles><smiles>C#CCOC(=O)c1ccc(OC)cc1</smiles><smiles>C=CCOCc1ccc(OCc2ccccc2)cc1</smiles><smiles>C=CCc1ccc(CO)cc1</smiles><smiles>O=C(Oc1ccc(CCl)cc1)c1ccccc1</smiles>

(1) Saino, N.; Kogure, D.; Kase, K.; Okamoto, S. J. Organomet. Chem. 2006, 691, 3129. Saino, N.; Amemiya, F.; Tanabe, E.; Kase, K.; Okamoto, S. Org. Lett. 2006, 8, 1439. Saino, N.; Kogure, D.; Okamoto, S. Org. Lett. 2005, 7, 3065.

(2) (a) For allyl ethers, see: Lee, K. Y.; Lee, M. J.; Kim, J. N. Tetrahedron 2005, 61, 8705. (b) Ranu, B. C.; Dutta, J.; Guchhait, S. K. J. Org. Chem. 2001, 66, 5624. (c) Dunn, J. A.; Pauson, P. L. J. Organomet. Chem. 1991, 419, 383. (d) Schneiderova, L.; Strouf, O.; Gruner, B.; Pouzar, V.; Drasar, P.; Hampl, R.; Kimlova, I. Collect. Czec. Chem. Commun. 1992, 57, 463. (e) Ashim, R.; Sahabuddin, S.; Basudeb, A.; Sukhendu, B. M. Tetrahedron 2005, 61, 365.

(3) For propargyl ethers, see: (a) Gozzo, F. C.; Fernandes, S. A.; Rodrigues, D. C.; Eberlin, M. N.; Marsaioli, A. J. J. Org. Chem. 2003, 68, 5493. (b) Haight, A. R.; Stoner, E. J.; Peterson, M. J.; Grover, V. K. J. Org. Chem. 2003, 68, 8092. (c) Bartoli, G.; Cupone, G.; Dalpozzo, R.; De Nino, A.; Maiuolo, L.; Marcantoni, E.; Procopio, A. Synlett 2001, 1897. (d) Bailey, W. F.; England, M. D.; Mealy, M. J.; Thongsornkleeb, C.; Teng, L. Org. Lett. 2000, 2, 489. (e) Taniguchi, T.; Ogasawara, K. Angew. Chem., Int. Ed. $1998,37,1136$.

(4) (a) Iwasaki, F.; Koyanagi, S.; Tsucha, S. Jpn. Kokai Tokkyo Koho, 06340590, 13 Dec 1994. (b) Genet, J. P.; Blart, E.; Savignac, M.; Lemeune, S.; Lemaire-Audoire, S.; Paris, J. M.; Bernard, J. Tetrahedron 1994, 50, 497. See also ref 3d.

(5) Green, T. W.; Wuts, P. G. M. Protective Groups in Organic Synthesis, 3rd ed.; Wiley: New York, 1999. 


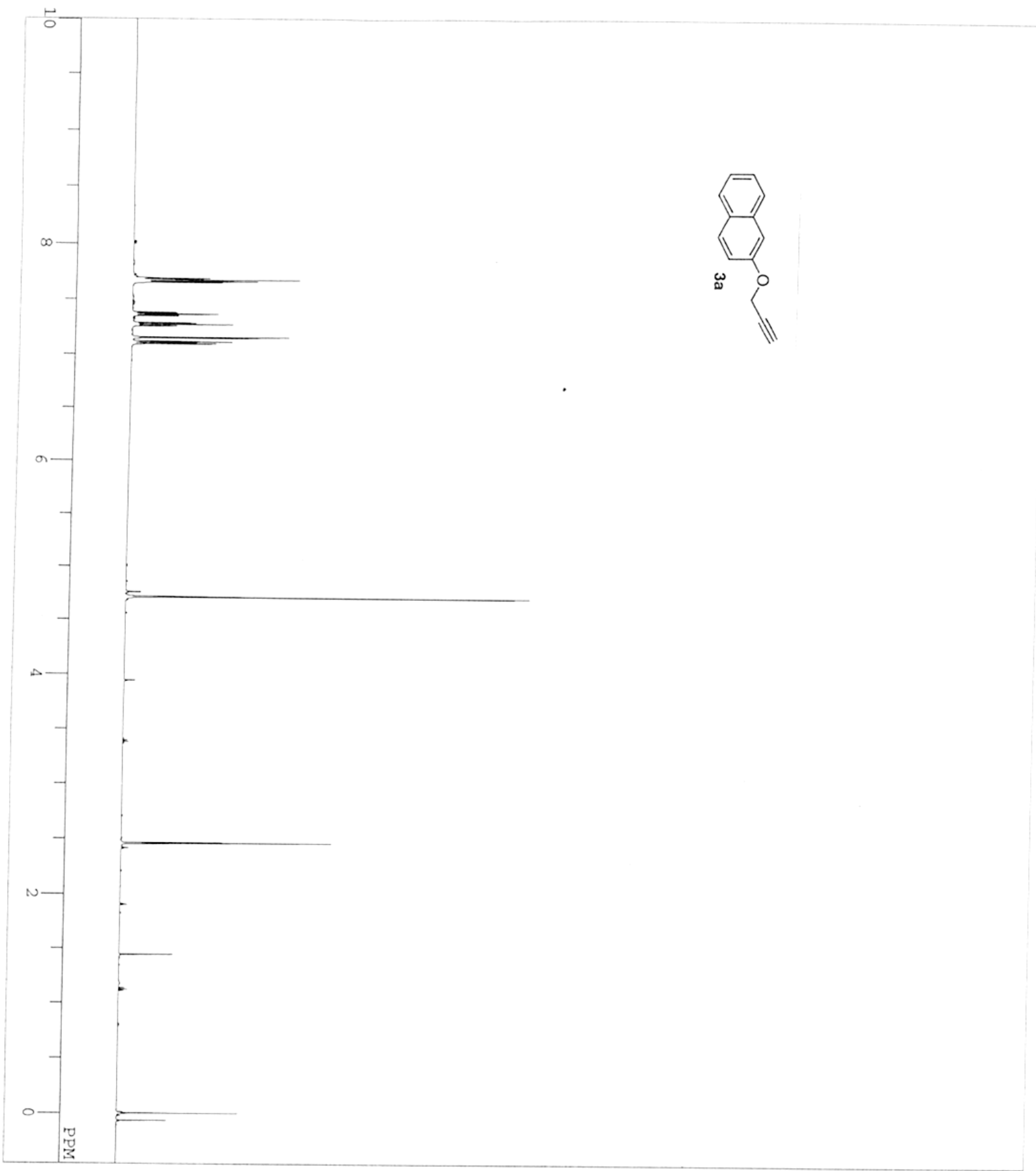

${ }^{1} \mathrm{H}$ NMR of $\mathbf{3 a}$

SI_2: page - 3 - 


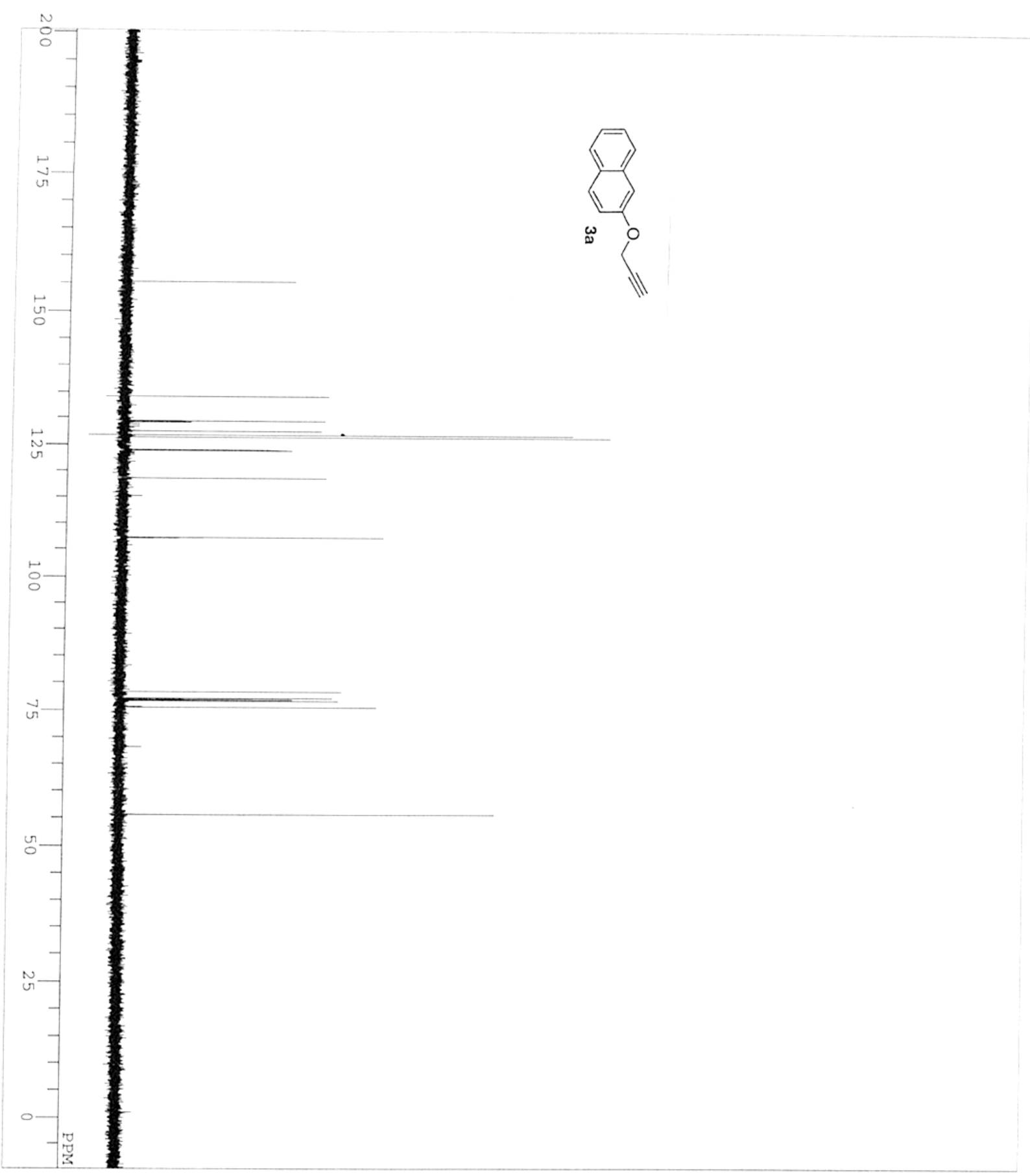

${ }^{13} \mathrm{C}$ NMR of 3a

SI_2: page - 4 - 


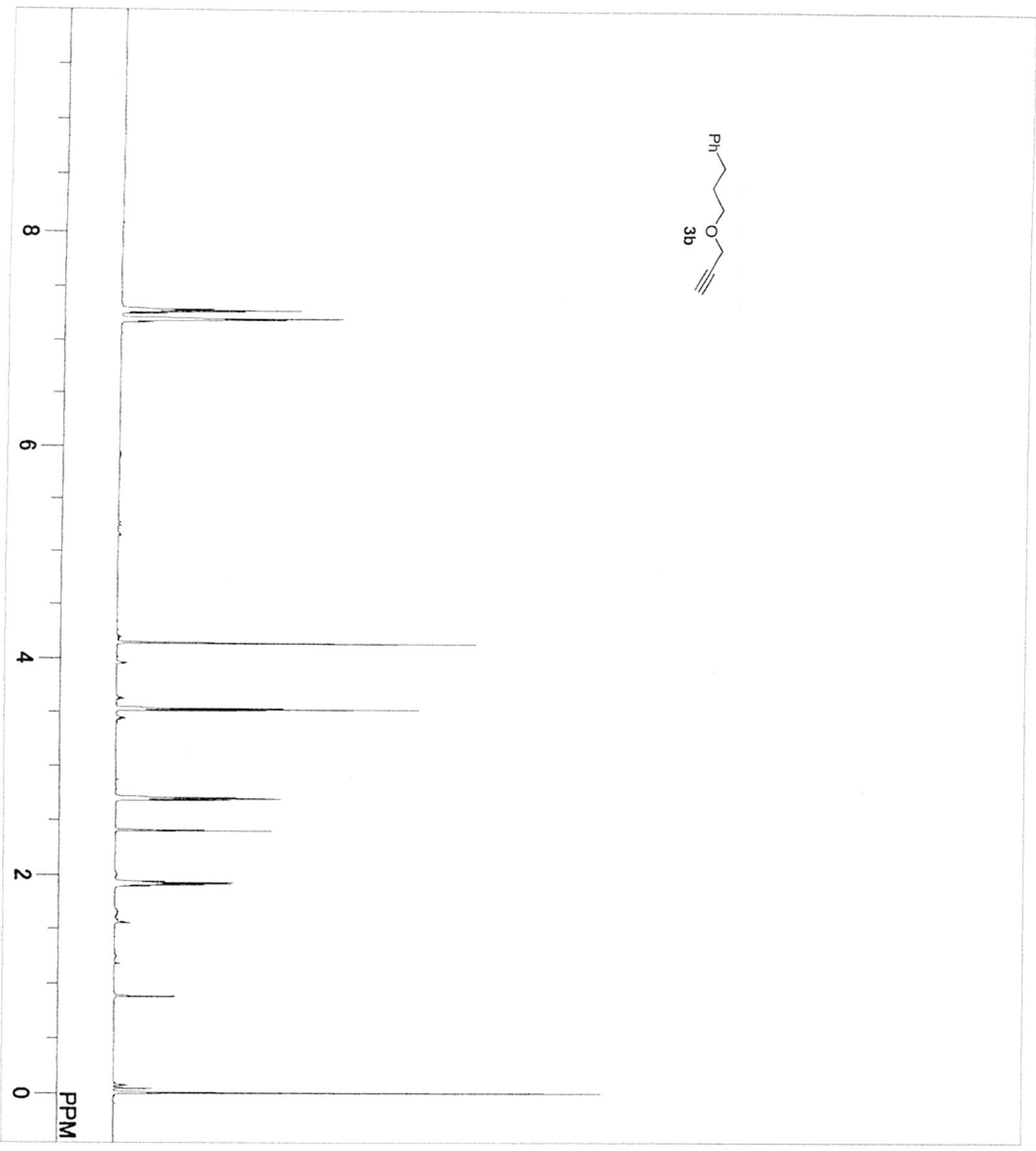

${ }^{1} \mathrm{H}$ NMR of $\mathbf{3 b}$

SI_2: page - 5 - 


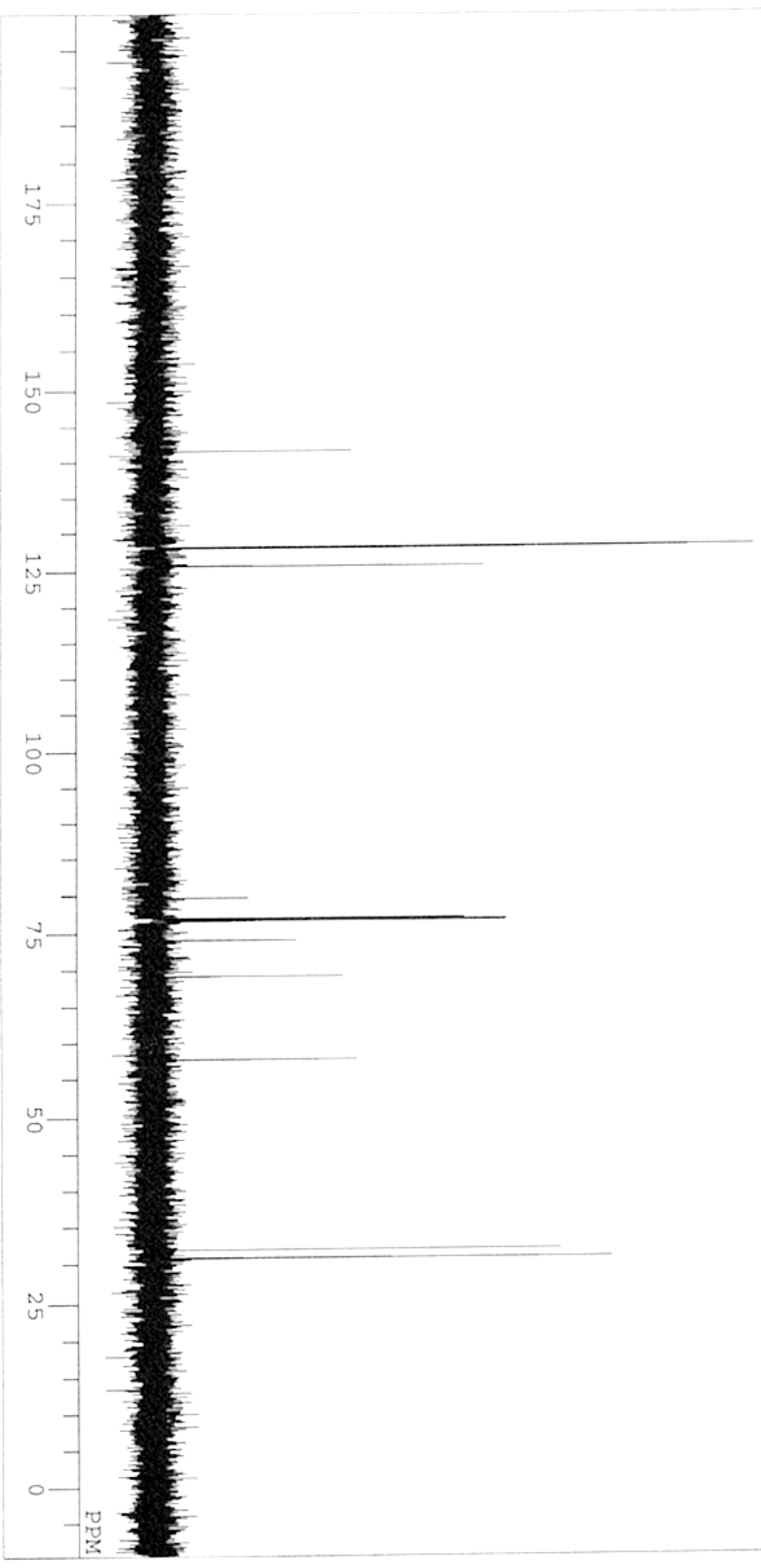

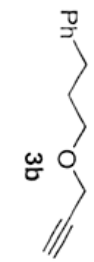

${ }^{13} \mathrm{C}$ NMR of $\mathbf{3 b}$

SI_2: page - 6 - 


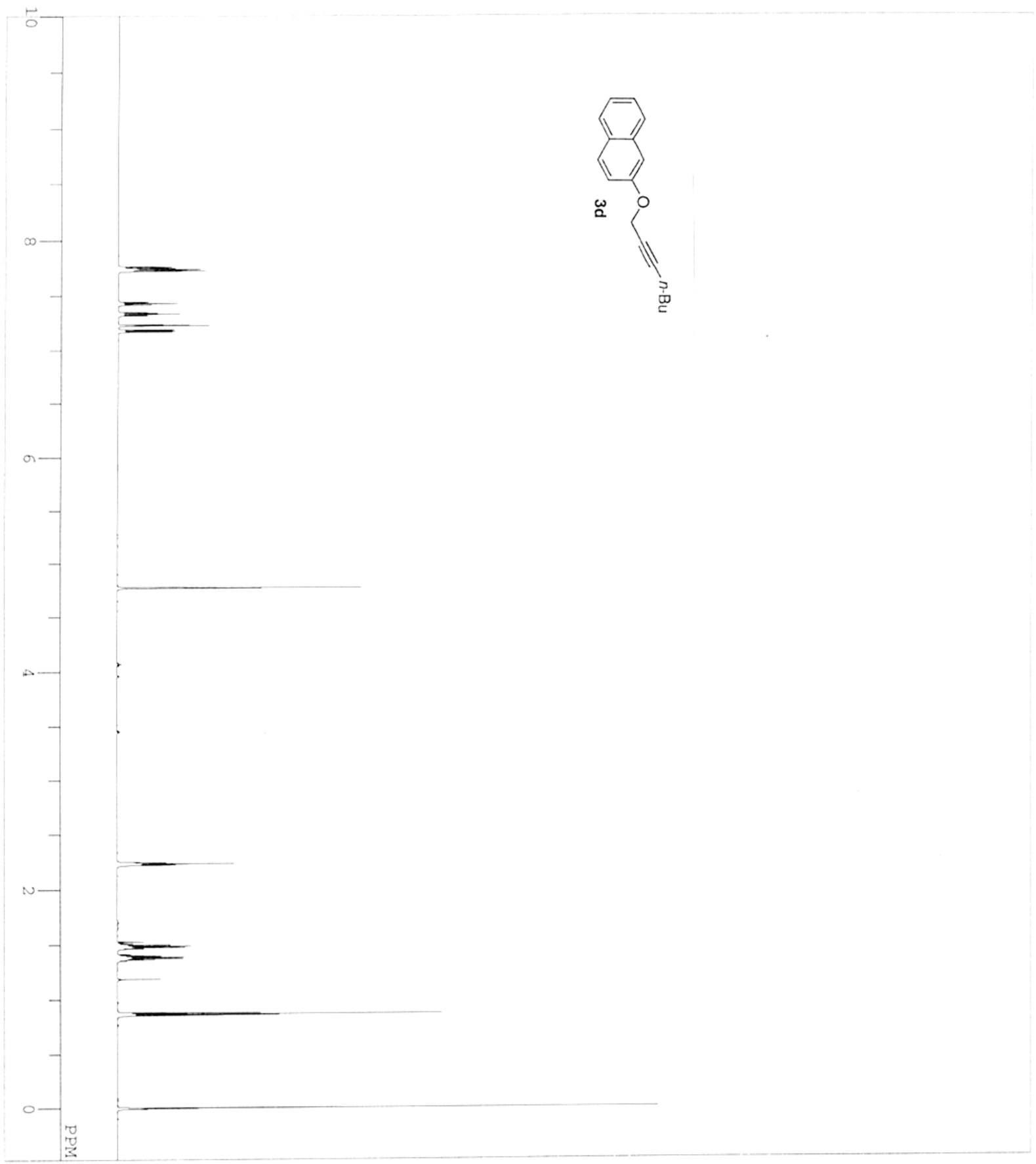

${ }^{1} \mathrm{H}$ NMR of $\mathbf{3 d}$

SI_2: page - 7 - 


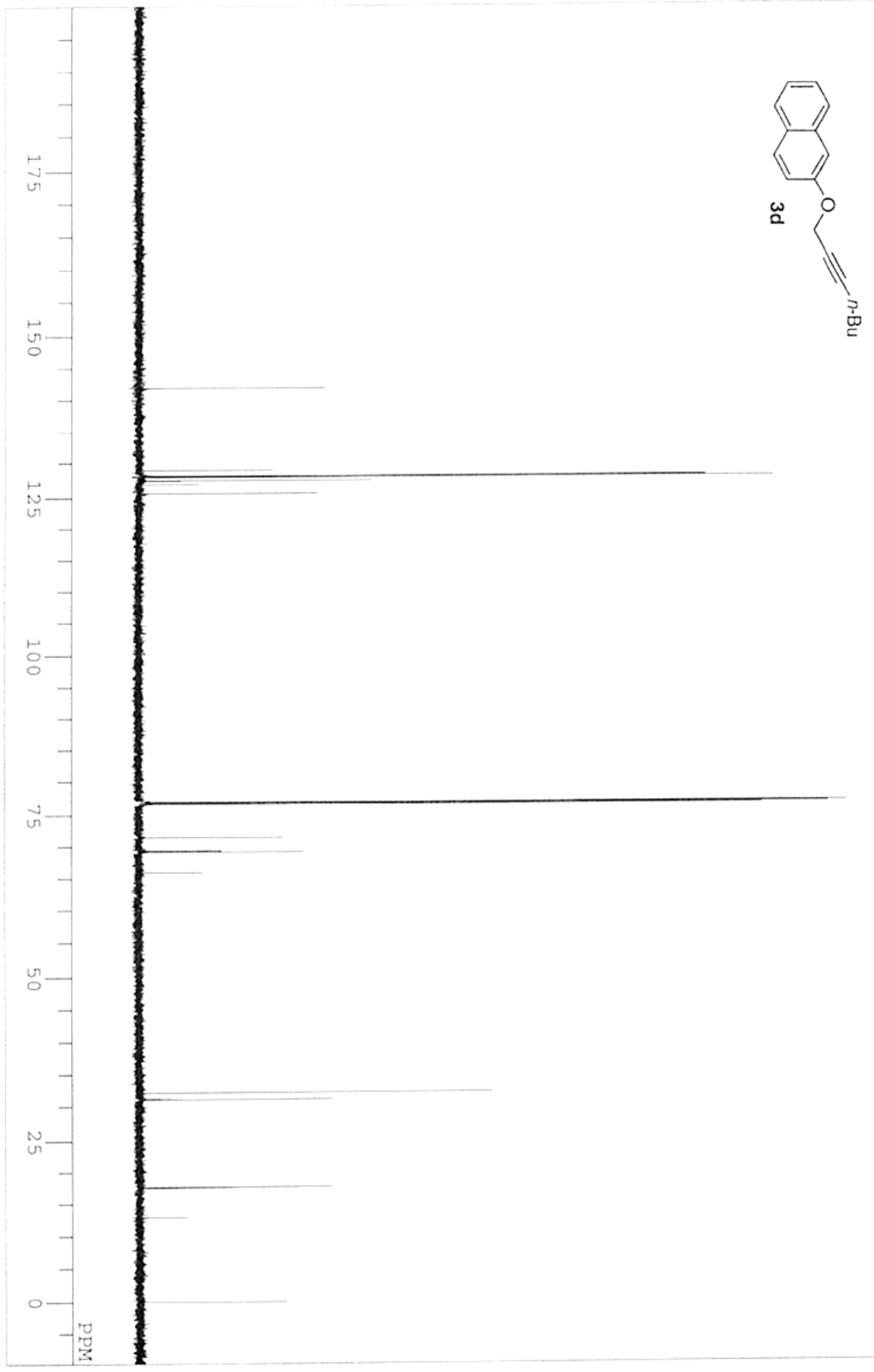

${ }^{13} \mathrm{C}$ NMR of 3d

SI_2: page - 8 - 


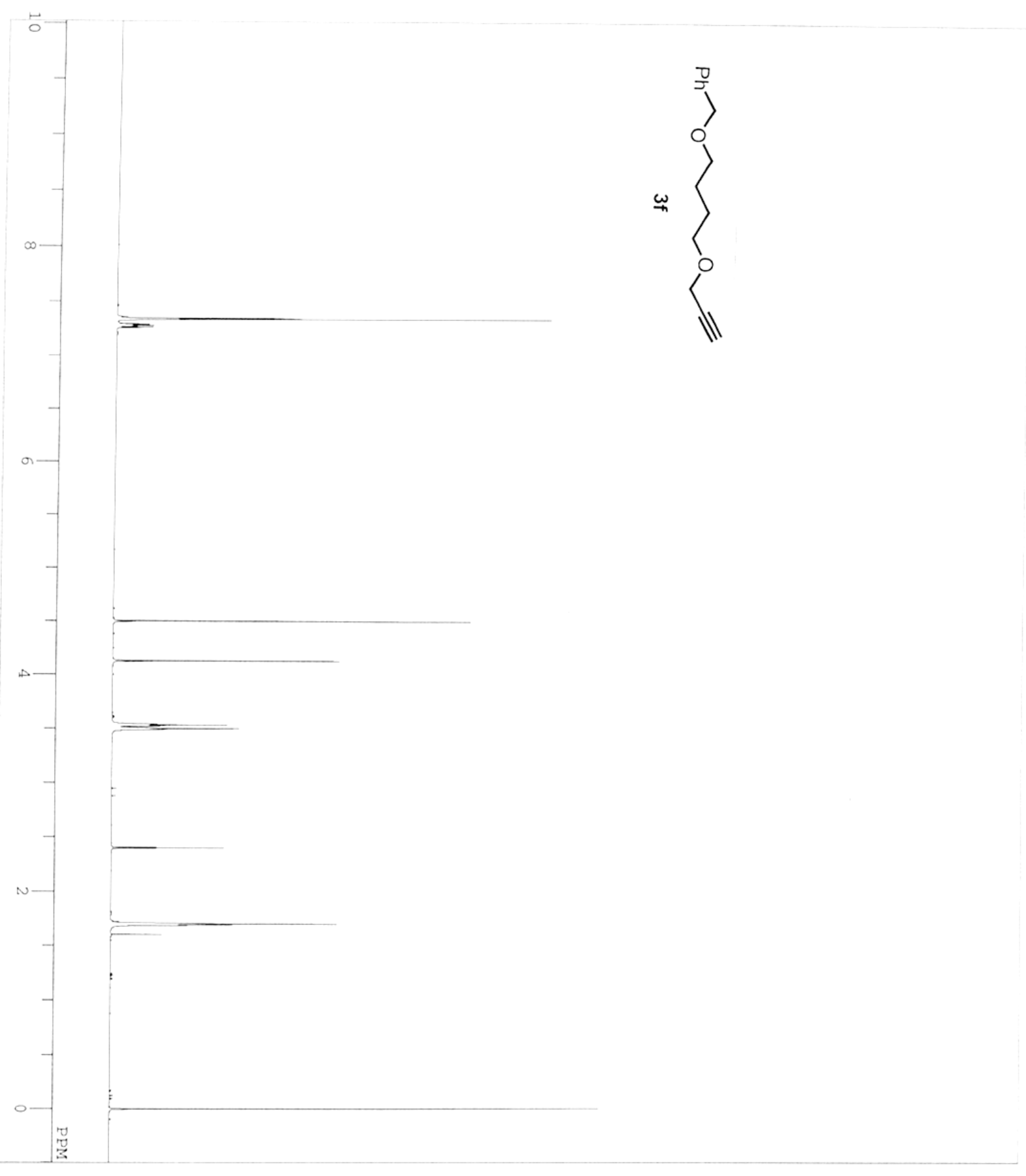

${ }^{1} \mathrm{H}$ NMR of $\mathbf{3 f}$

SI_2: page-9 - 


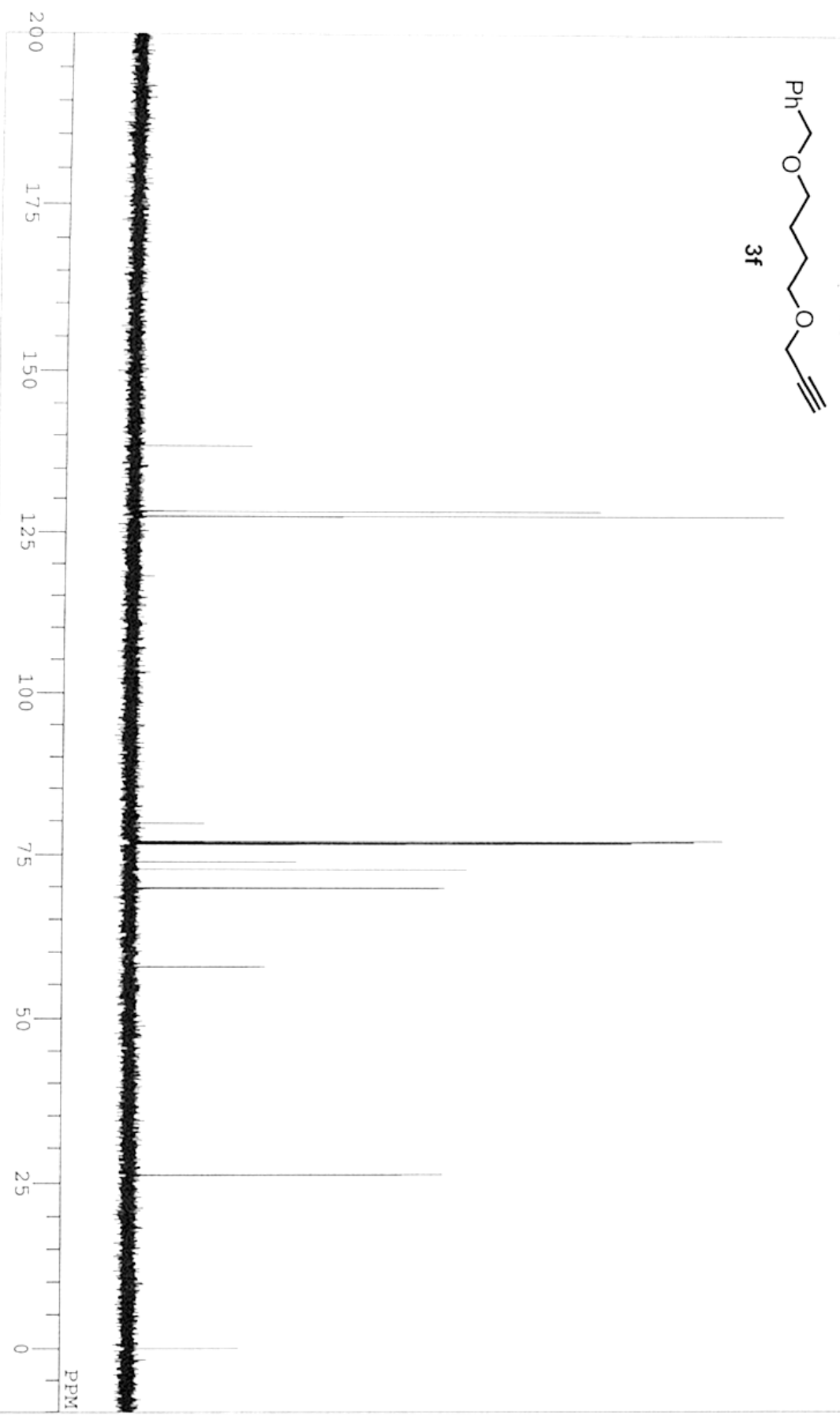

${ }^{13} \mathrm{C}$ NMR of $\mathbf{3 f}$

SI_2: page - 10 - 


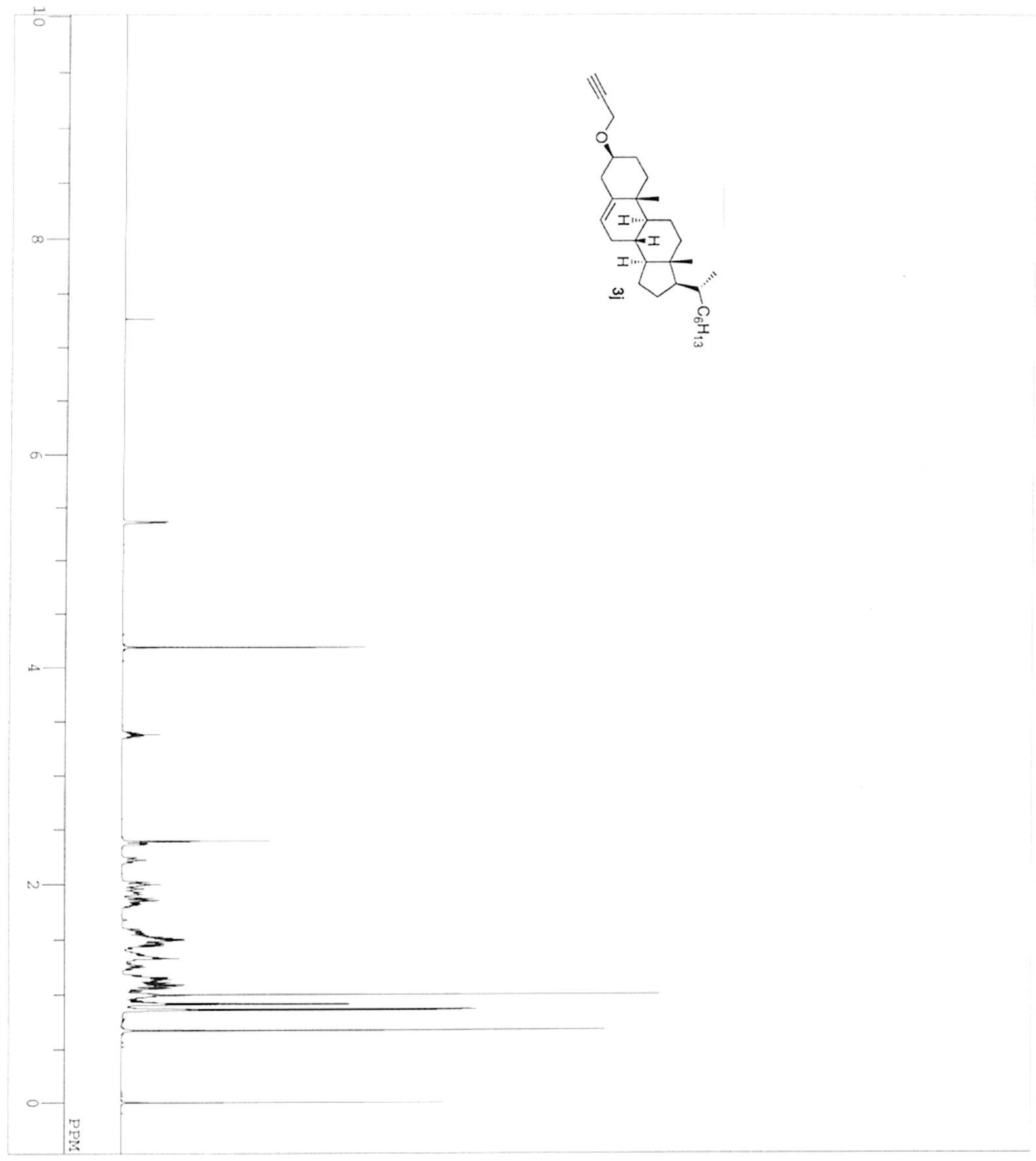

${ }^{1} \mathrm{H}$ NMR of $\mathbf{3 j}$

SI_2: page - 11 - 


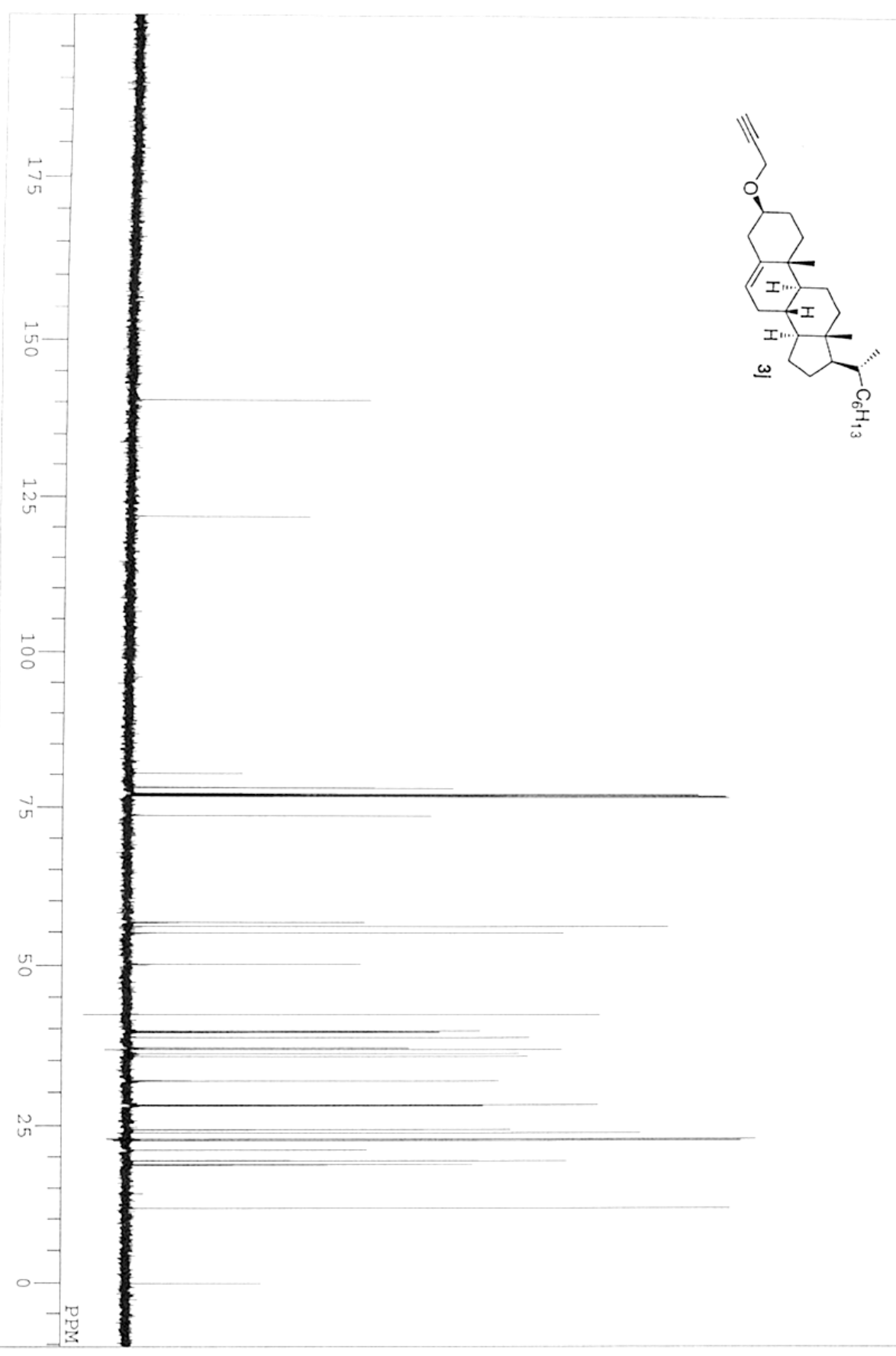

${ }^{13} \mathrm{C}$ NMR of $\mathbf{3 j}$ 


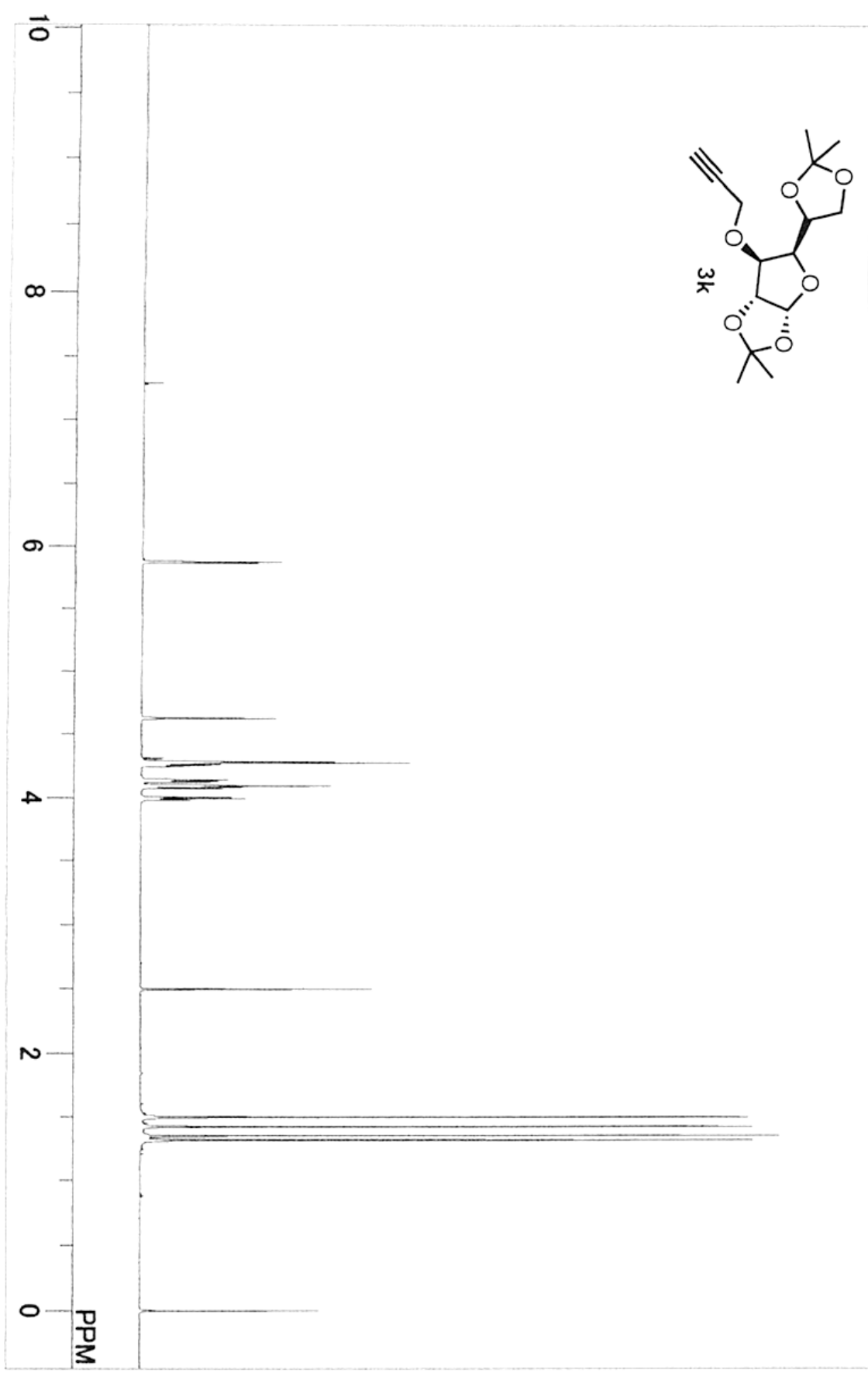

${ }^{1} \mathrm{H}$ NMR of $\mathbf{3 k}$

SI_2: page - 13 - 


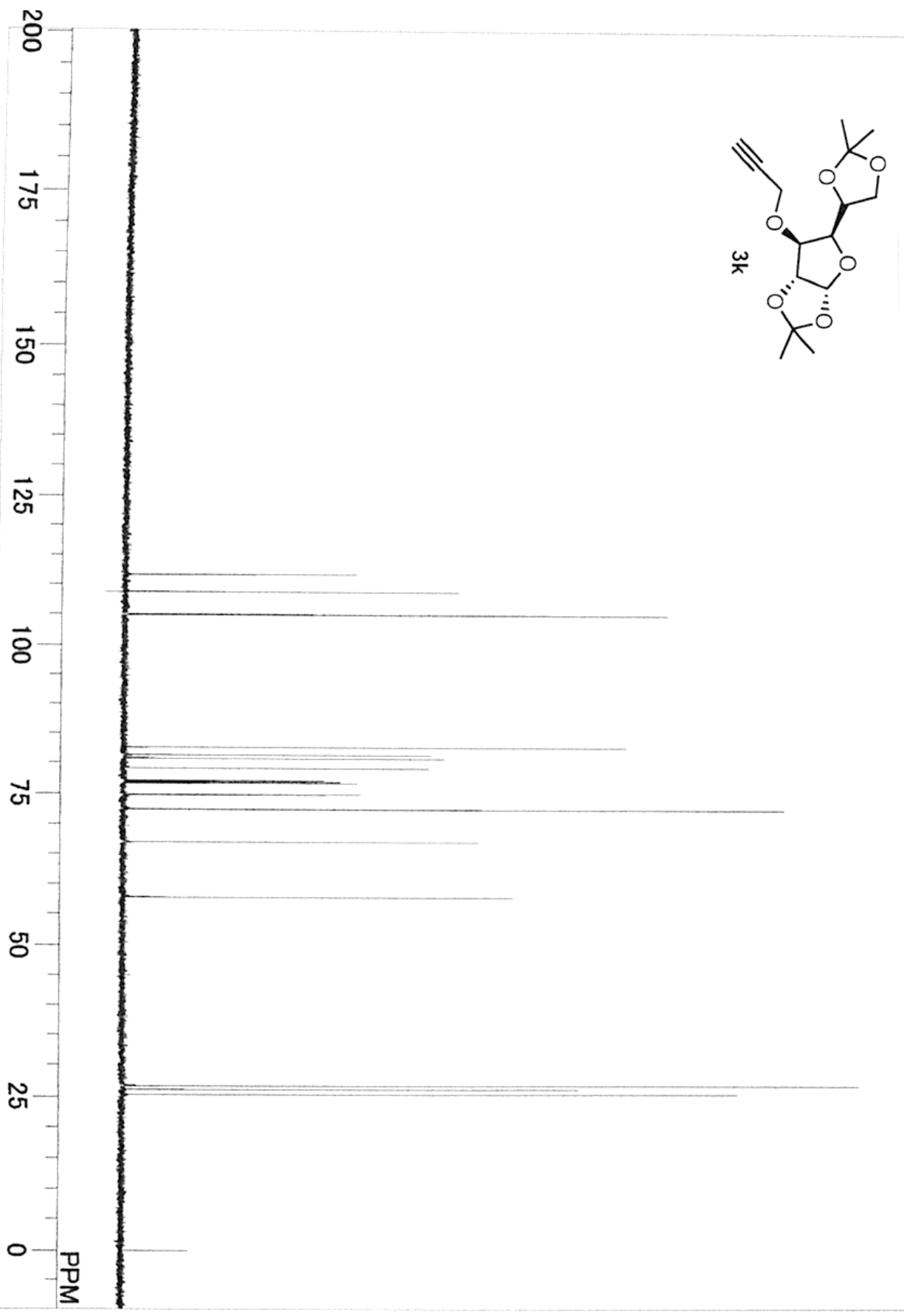

${ }^{13} \mathrm{C}$ NMR of 3k 


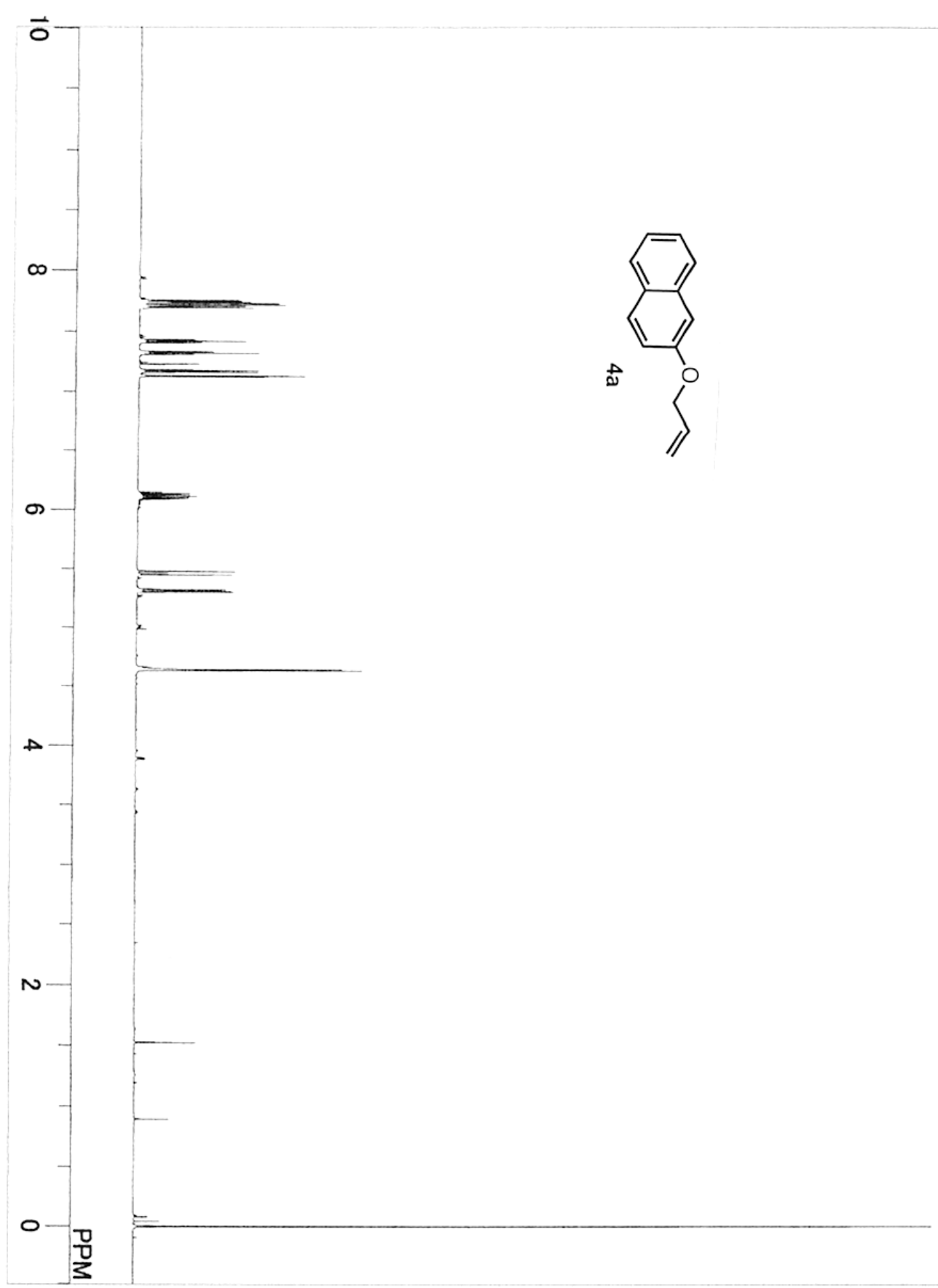

${ }^{1} \mathrm{H}$ NMR of $\mathbf{4 a}$

SI_2: page - 15 - 


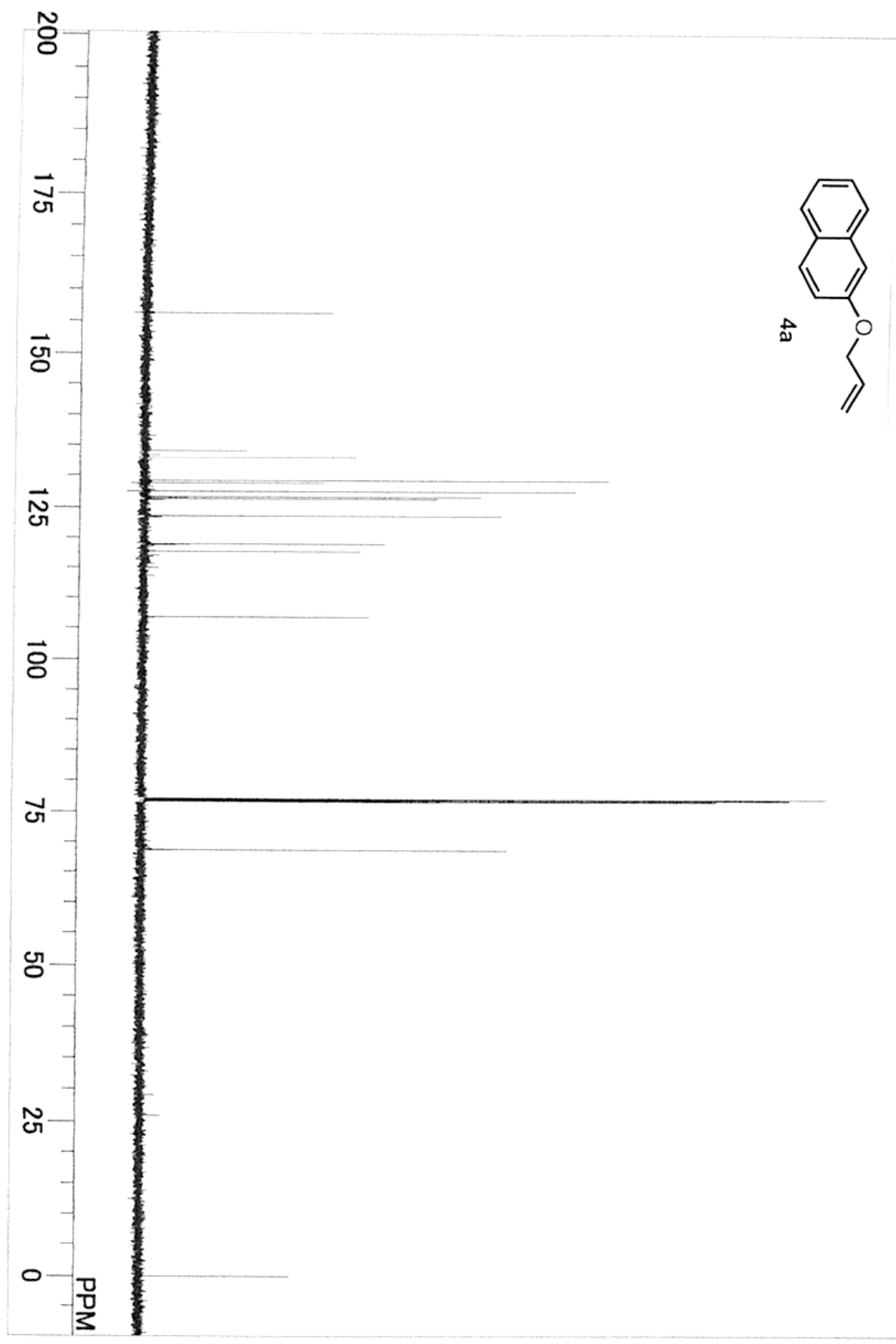

${ }^{13} \mathrm{C}$ NMR of $4 \mathbf{a}$ 

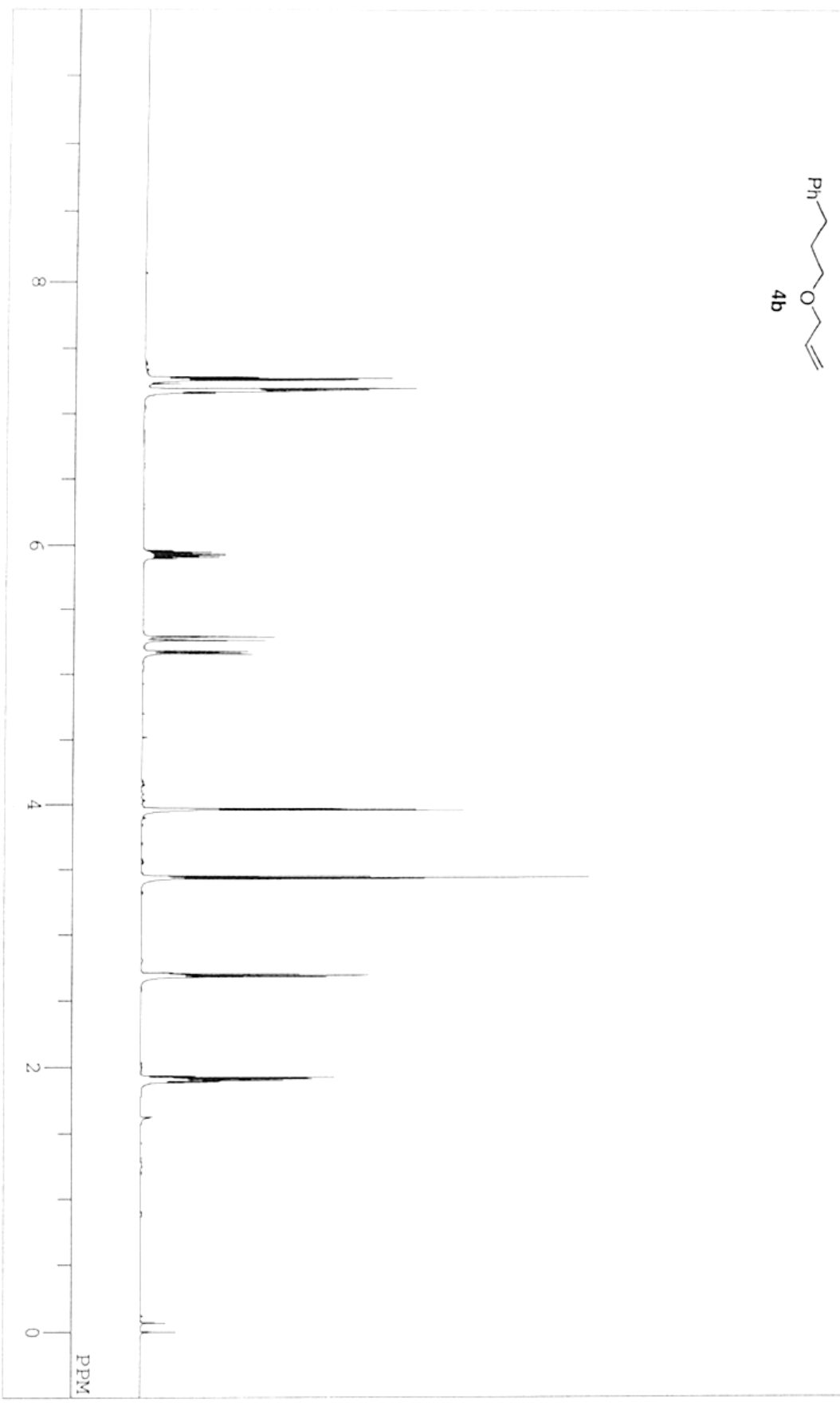

${ }^{1} \mathrm{H}$ NMR of $\mathbf{4 b}$

SI_2: page - 17 - 


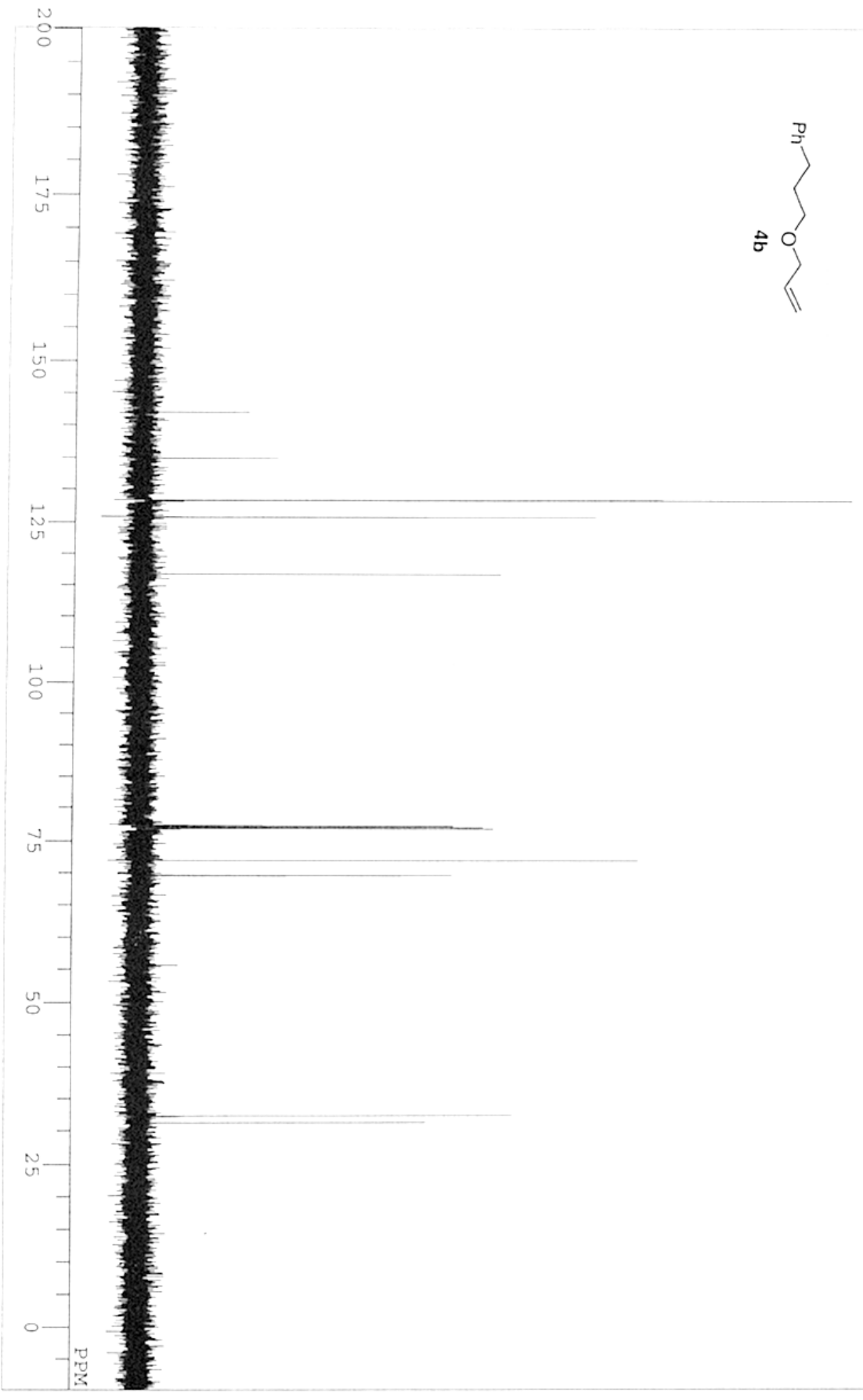

${ }^{13} \mathrm{C}$ NMR of $\mathbf{4 b}$

SI_2: page - 18 - 


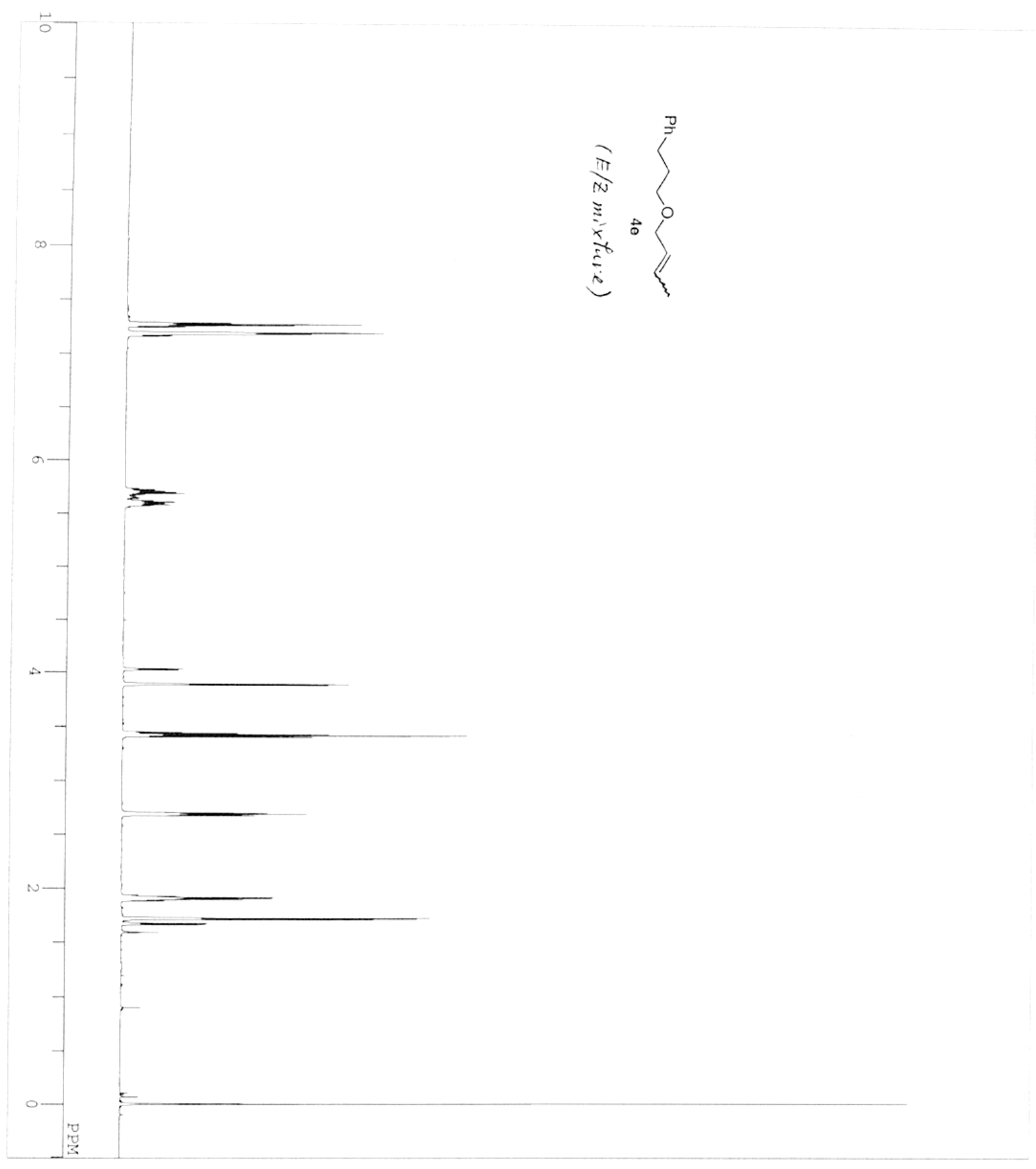

${ }^{1} \mathrm{H}$ NMR of $4 \mathbf{e}$ (a mixtutre of $E$ and $Z$ isomers) 


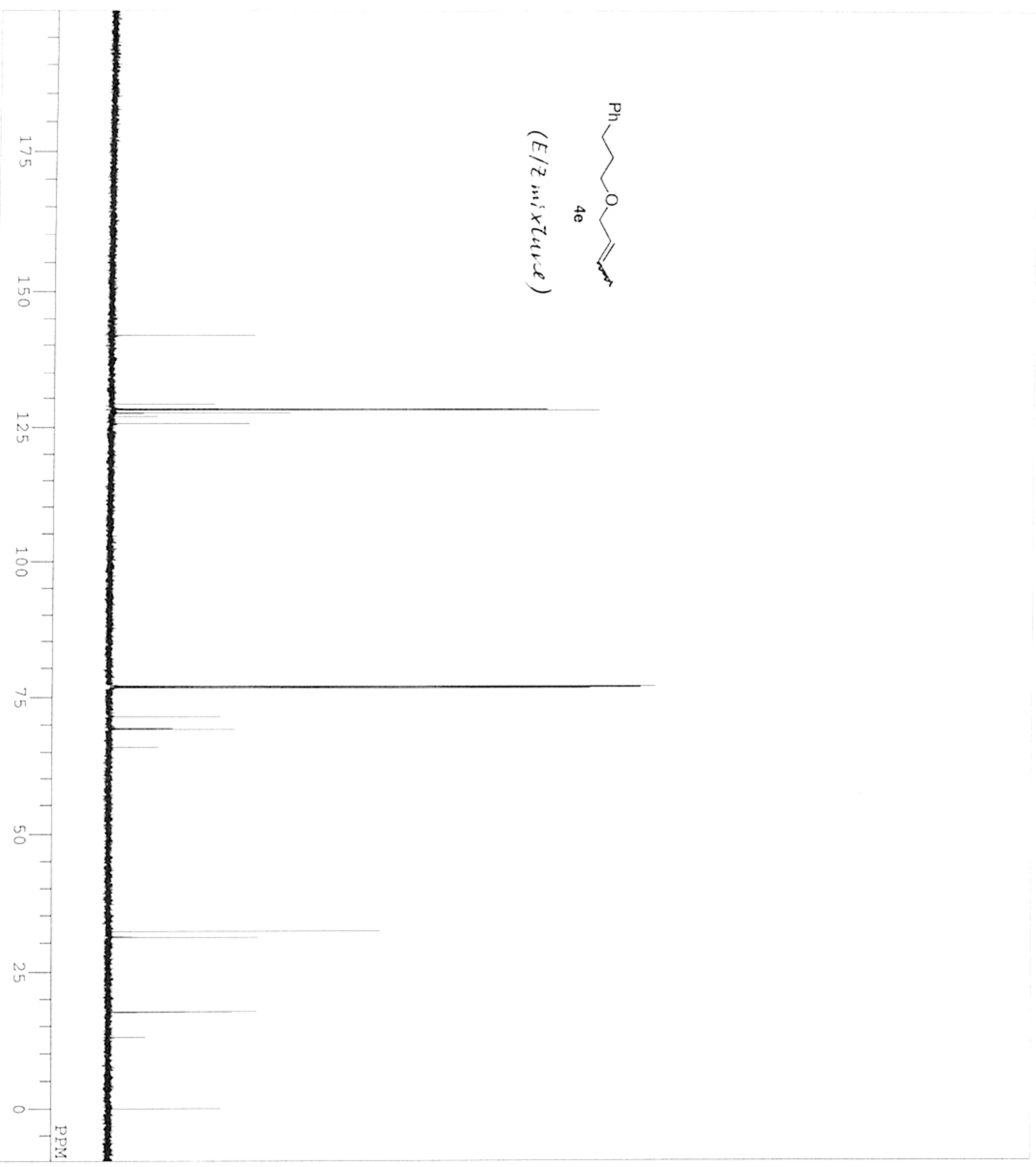

${ }^{13} \mathrm{C}$ NMR of $4 \mathbf{e}$ (a mixtutre of $E$ and $Z$ isomers) 


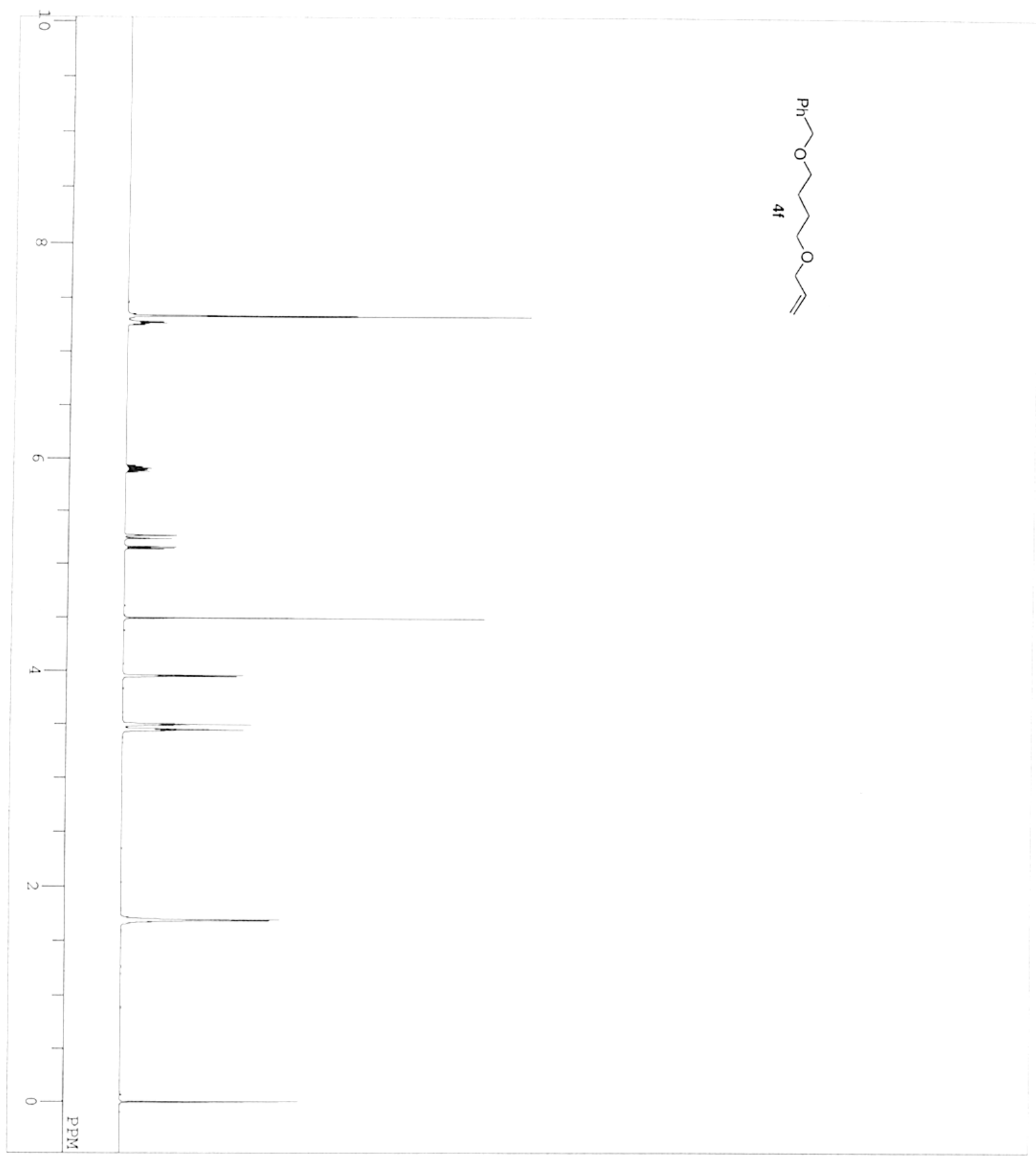

${ }^{1}$ H NMR of $\mathbf{4 f}$

SI_2: page - 21 - 


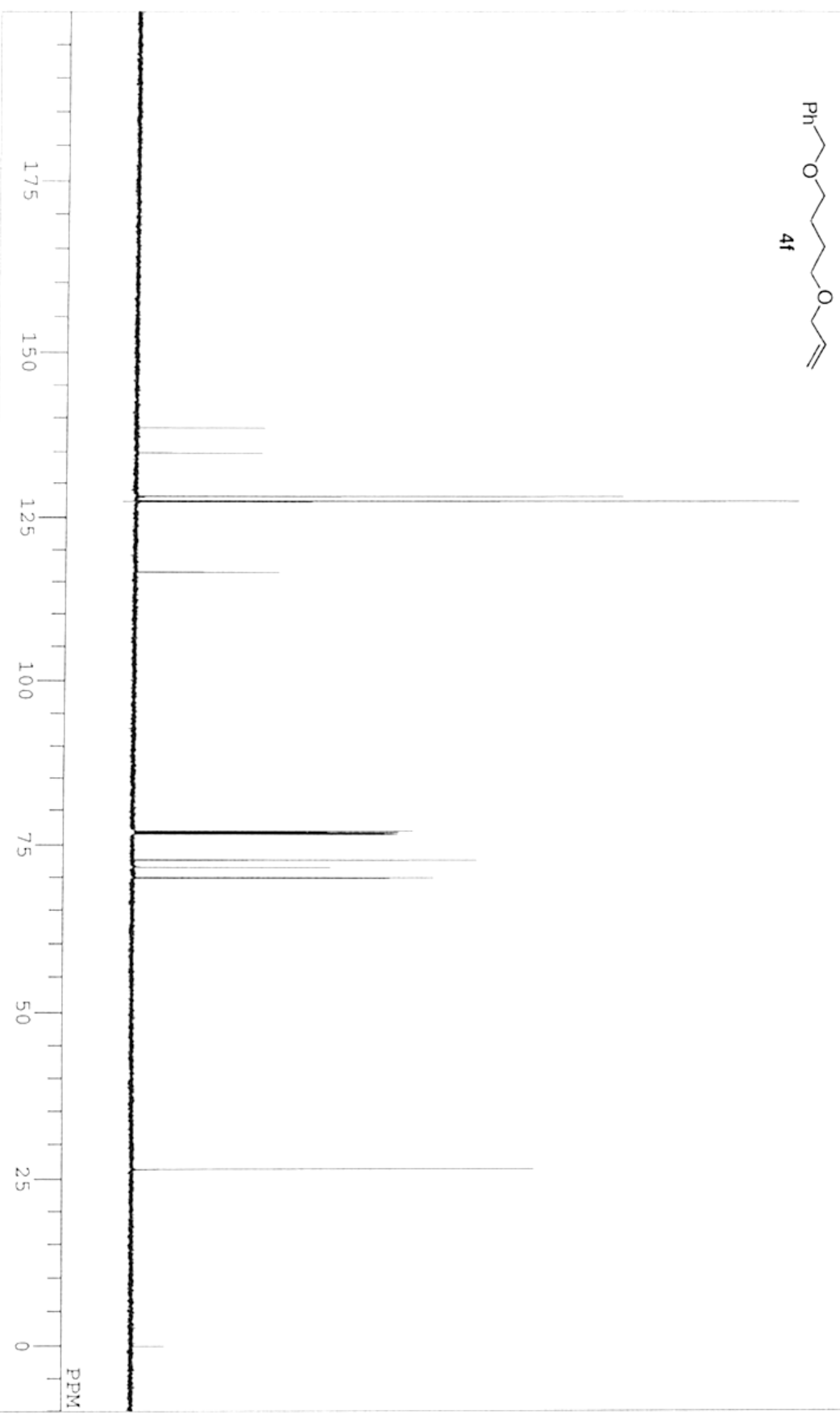

${ }^{13} \mathrm{C}$ NMR of $\mathbf{4 f}$

SI_2: page - 22 - 


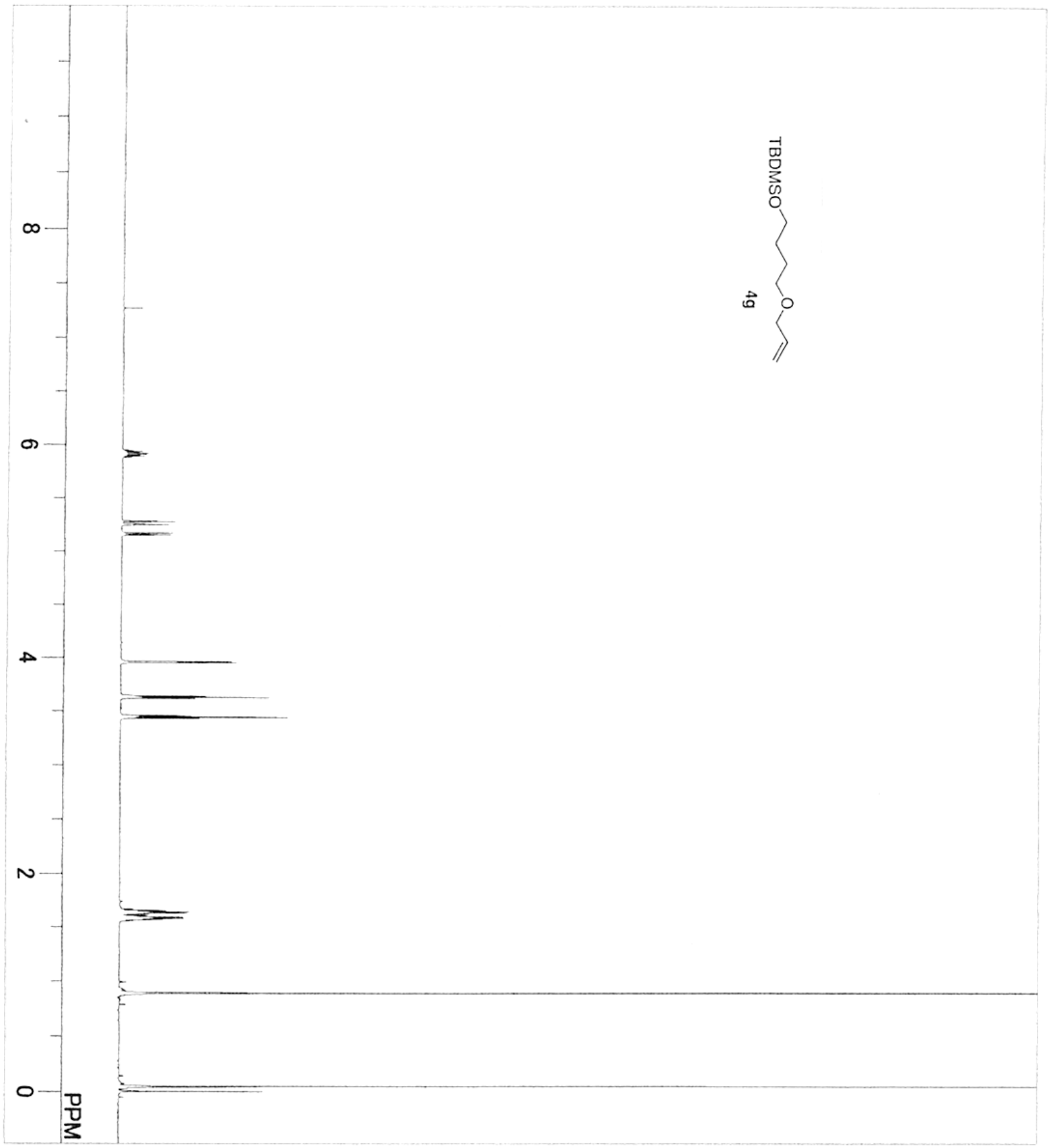

${ }^{1} \mathrm{H}$ NMR of $\mathbf{4 g}$

SI_2: page - 23 - 


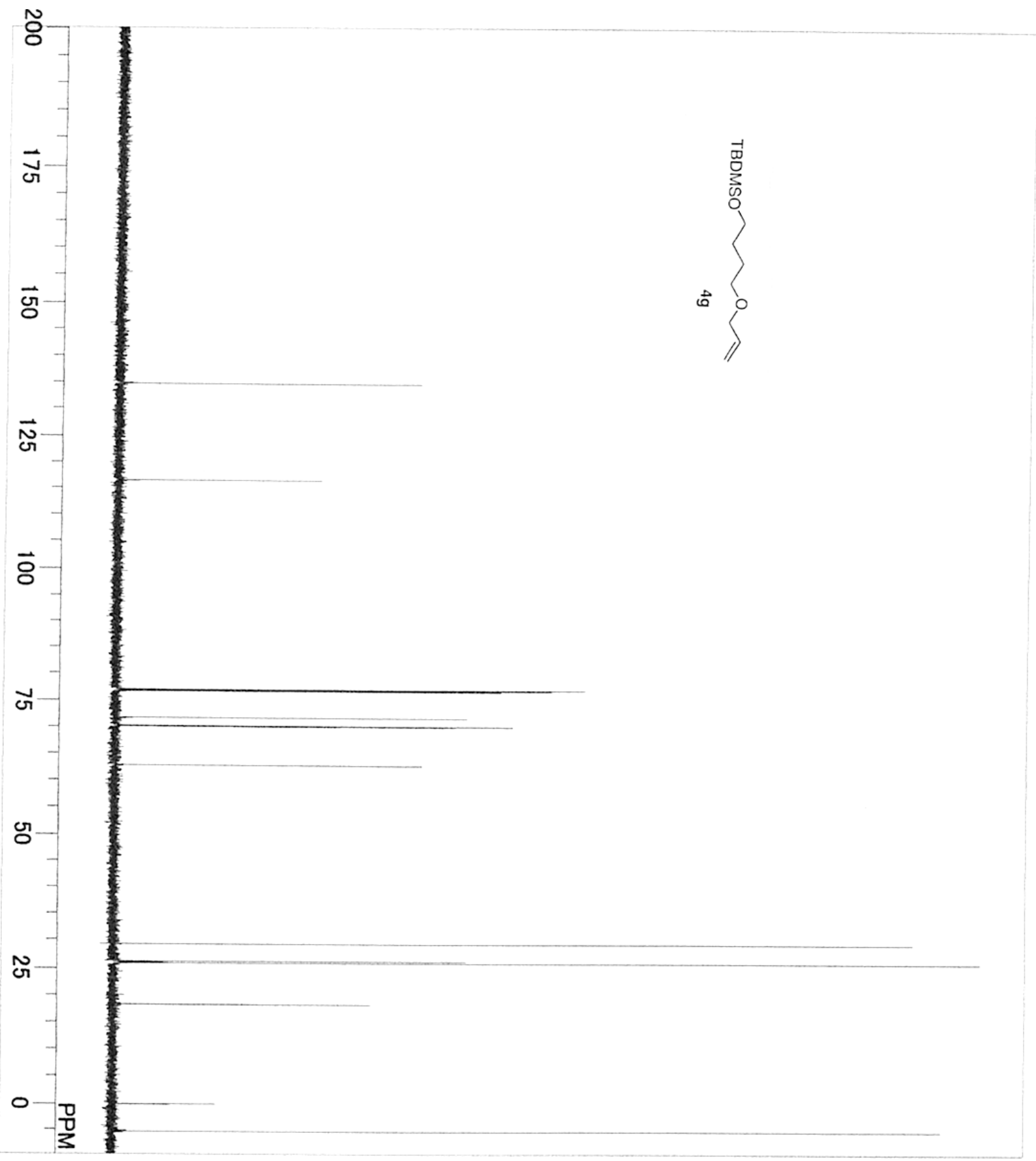

${ }^{13} \mathrm{C}$ NMR of $4 \mathrm{~g}$

SI_2: page - 24 - 


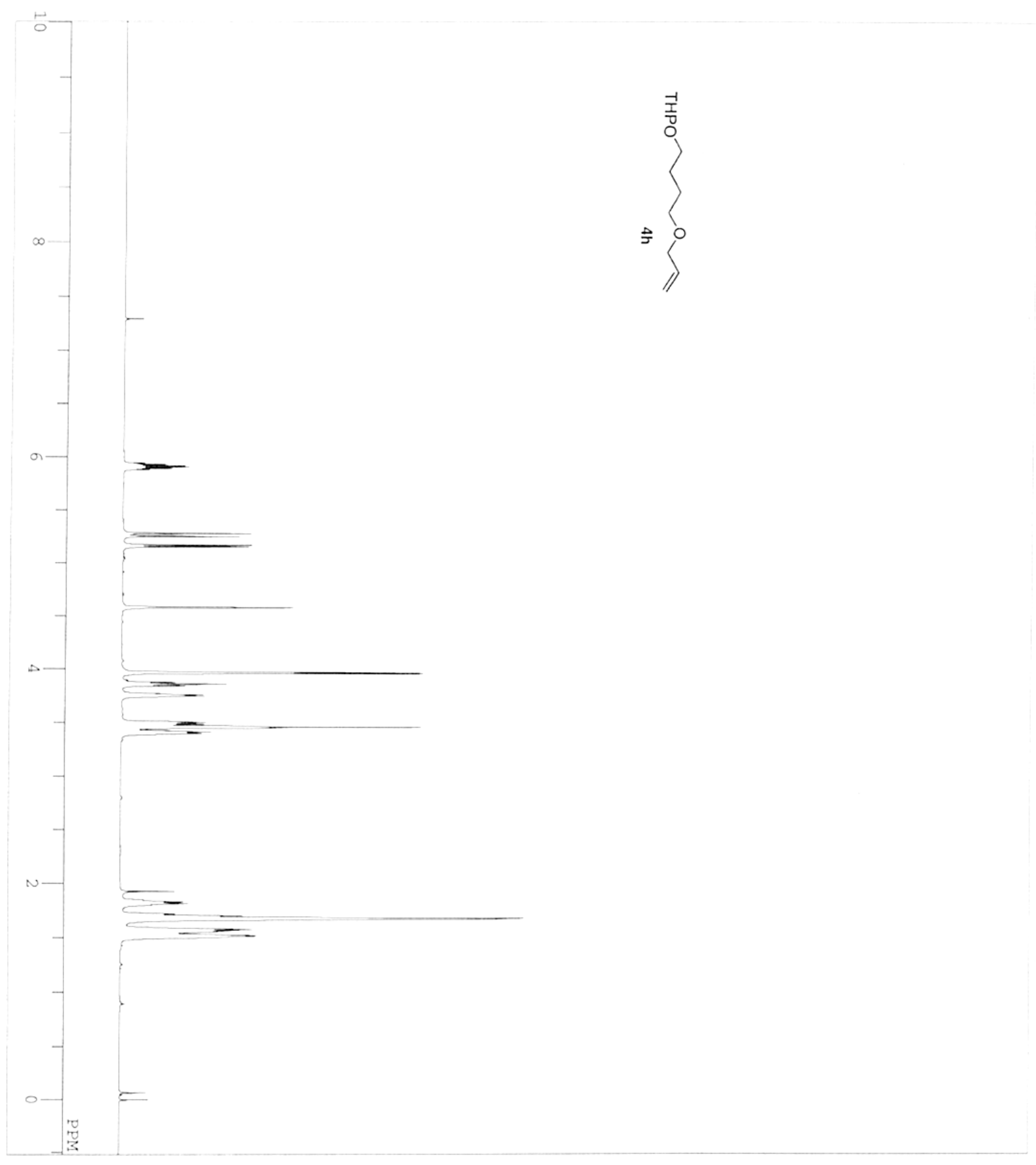

${ }^{1} \mathrm{H}$ NMR of $\mathbf{4 h}$

SI_2: page - 25 - 


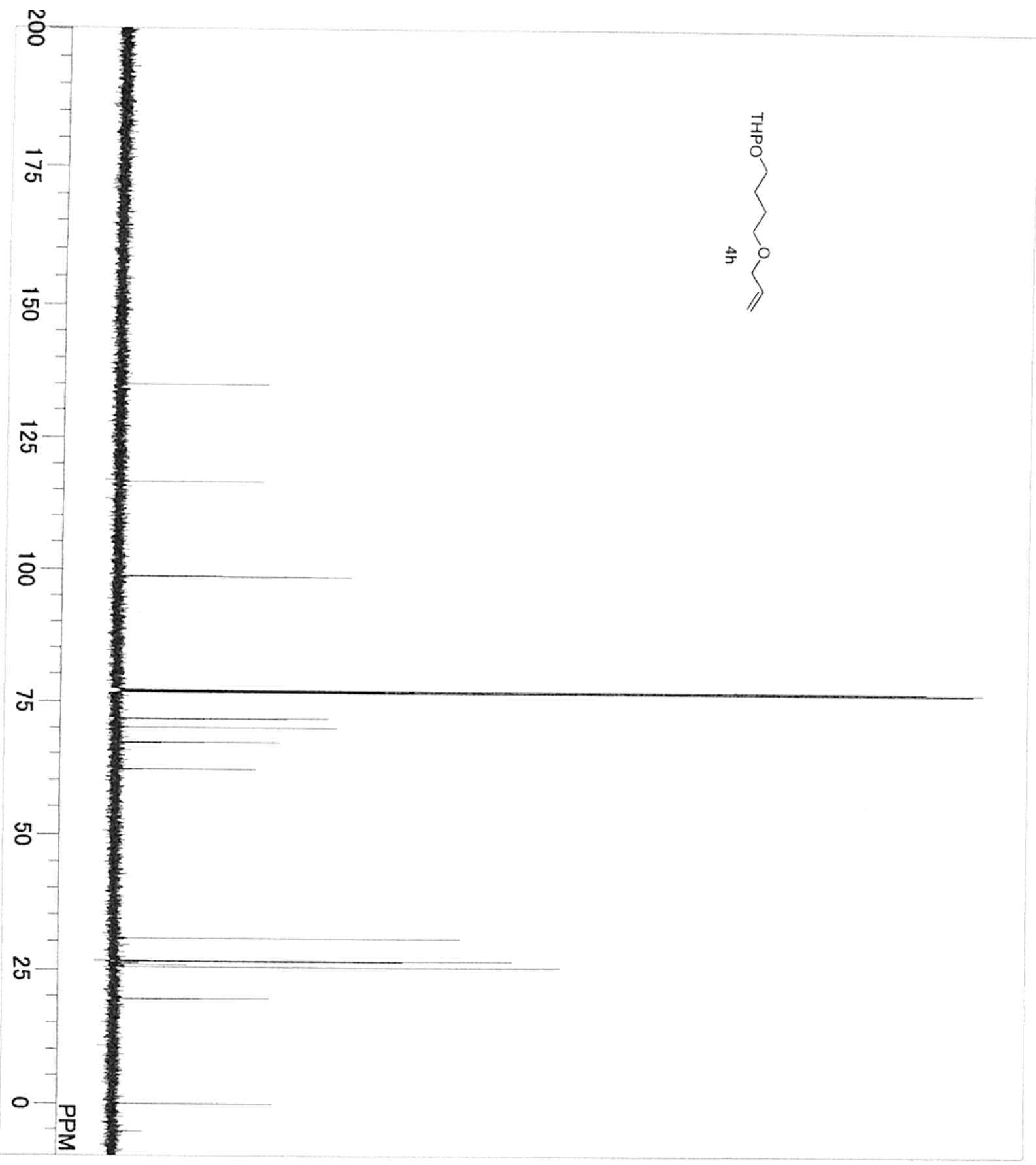

${ }^{13}$ C NMR of $4 h$

SI_2: page - 26 - 


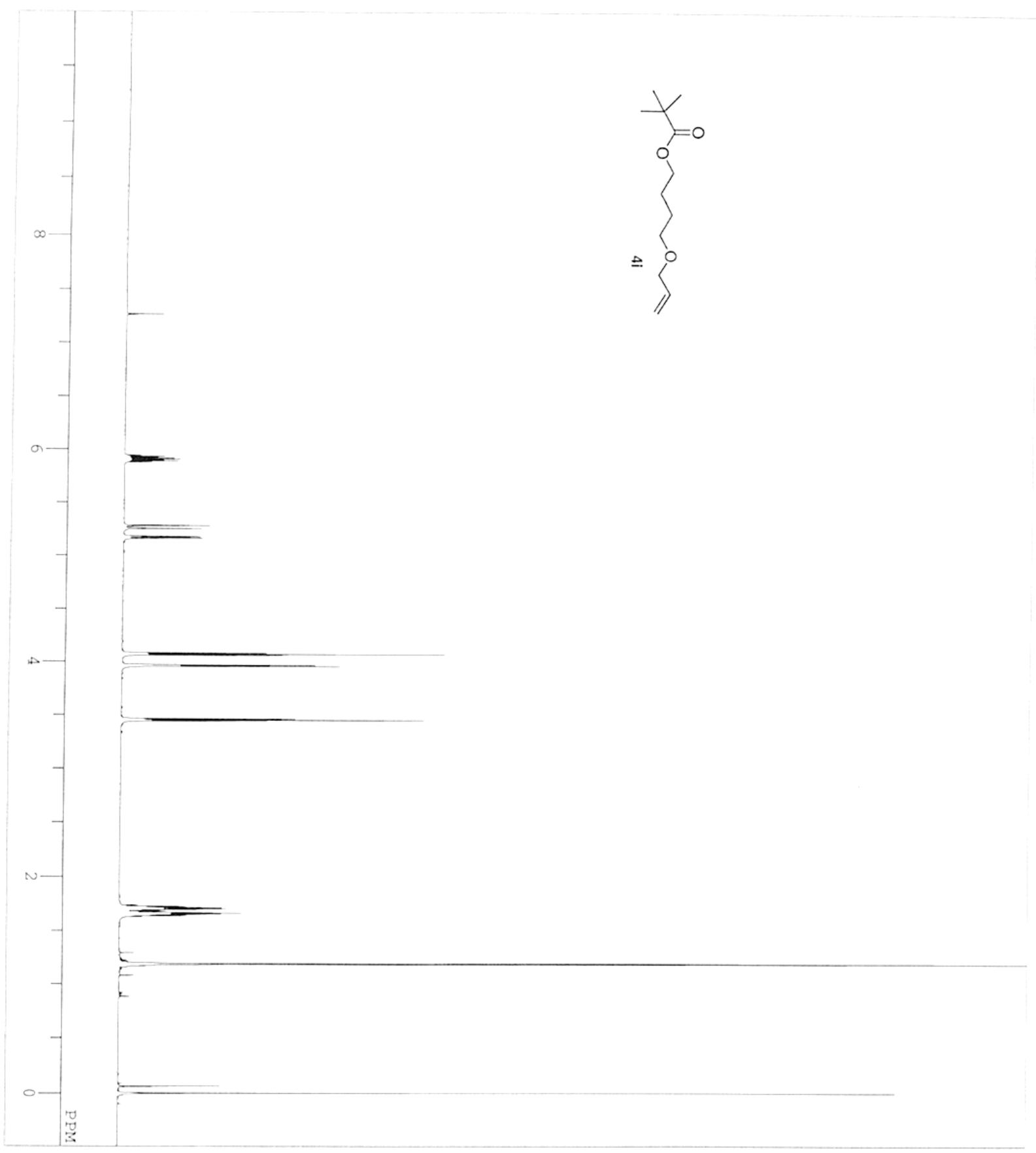

${ }^{1}$ H NMR of 4i

SI_2: page - 27 - 


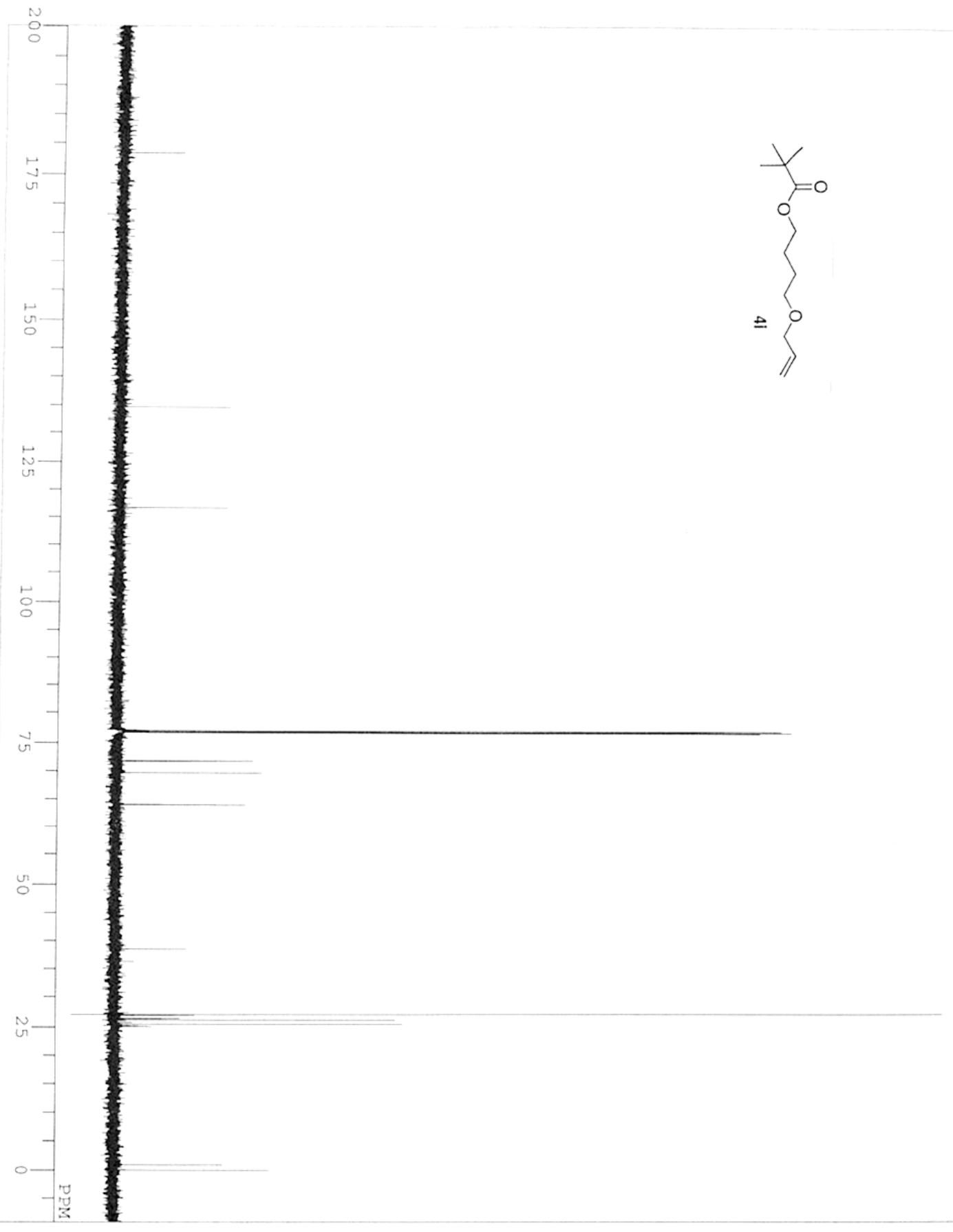

${ }^{13} \mathrm{C}$ NMR of $4 \mathbf{i}$

SI_2: page - 28 - 


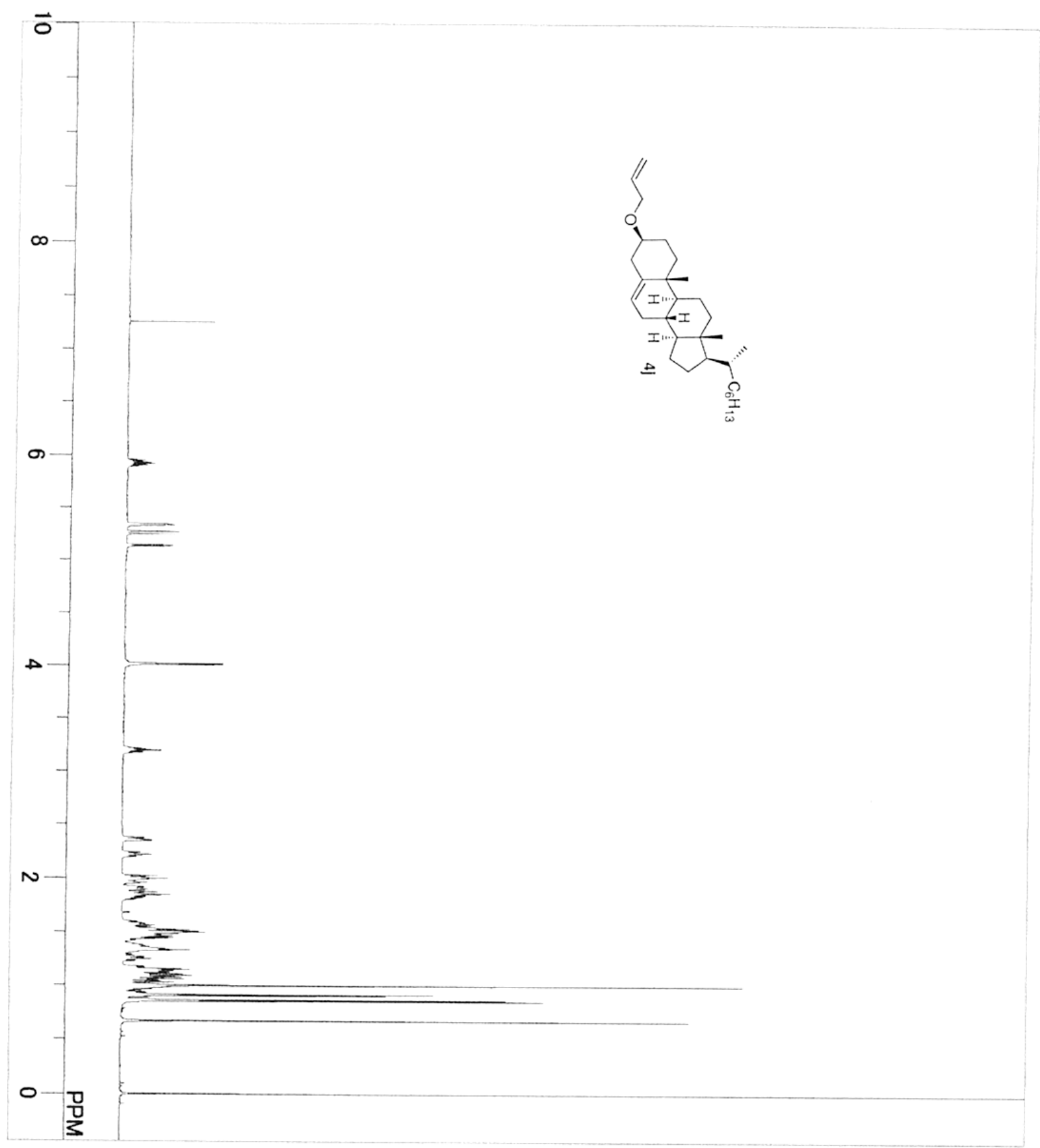

${ }^{1} \mathrm{H}$ NMR of $\mathbf{4 j}$ 


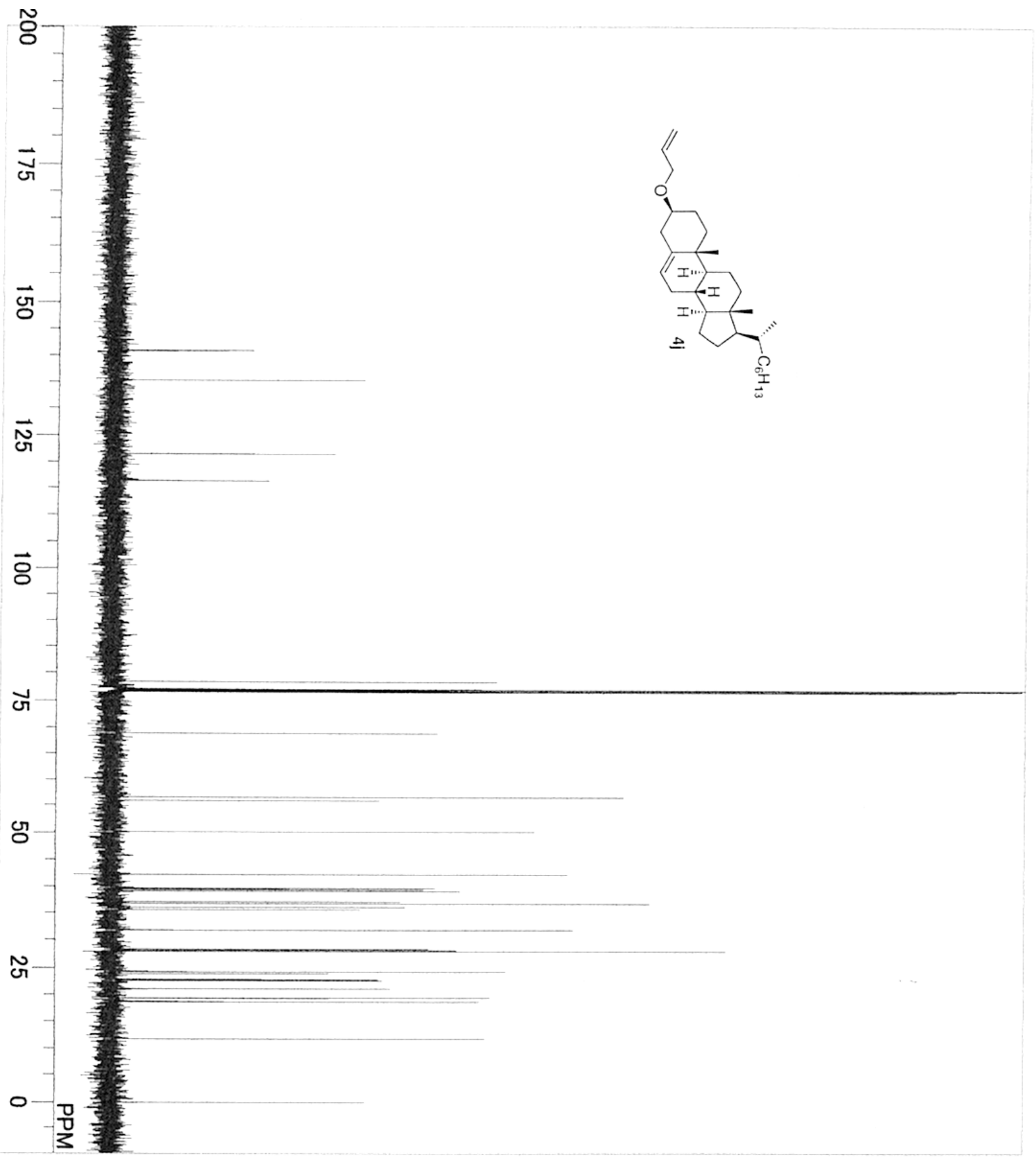

${ }^{13} \mathrm{C}$ NMR of $\mathbf{4 j}$ 


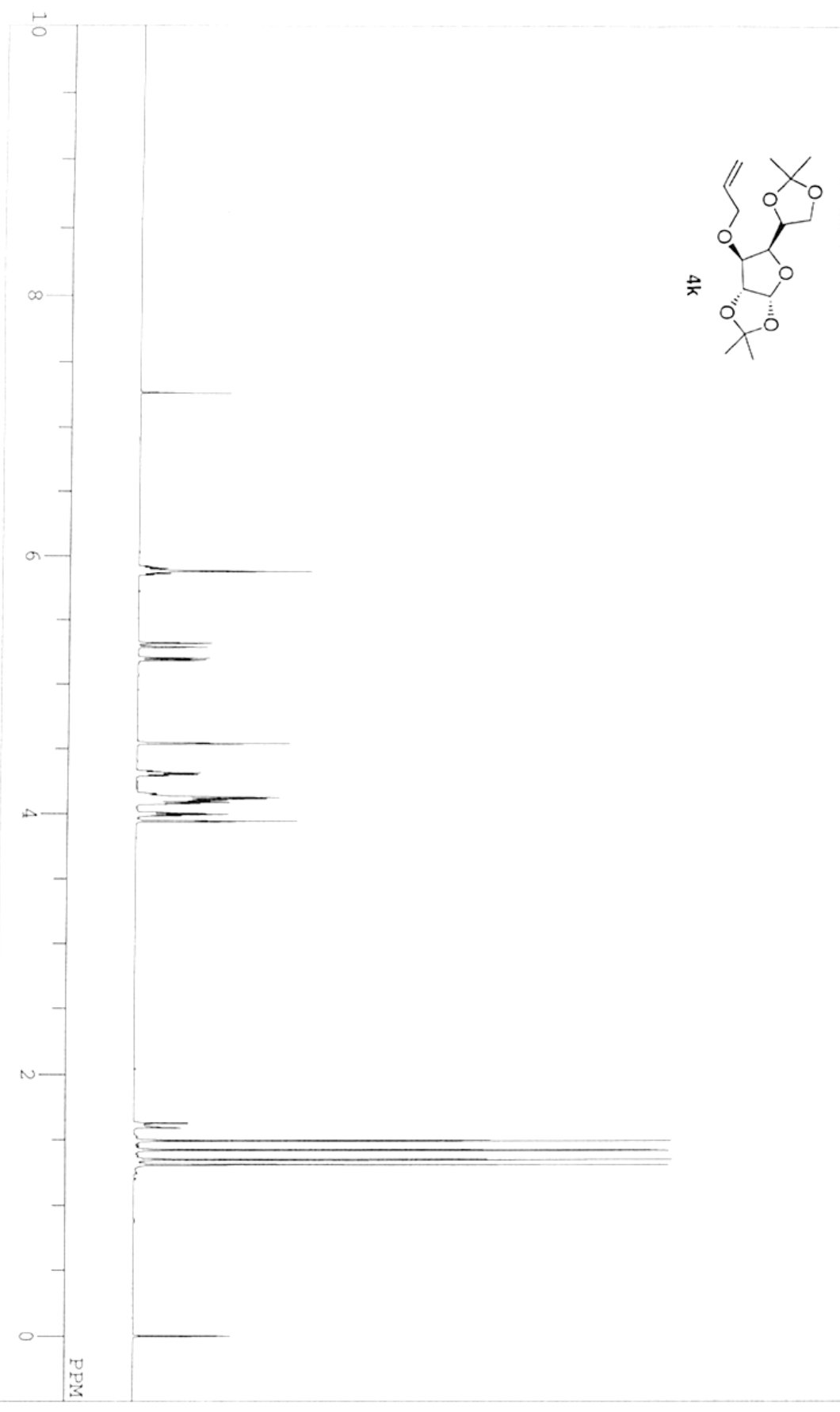

${ }^{1} \mathrm{H}$ NMR of $\mathbf{4 k}$

SI_2: page - 31 - 


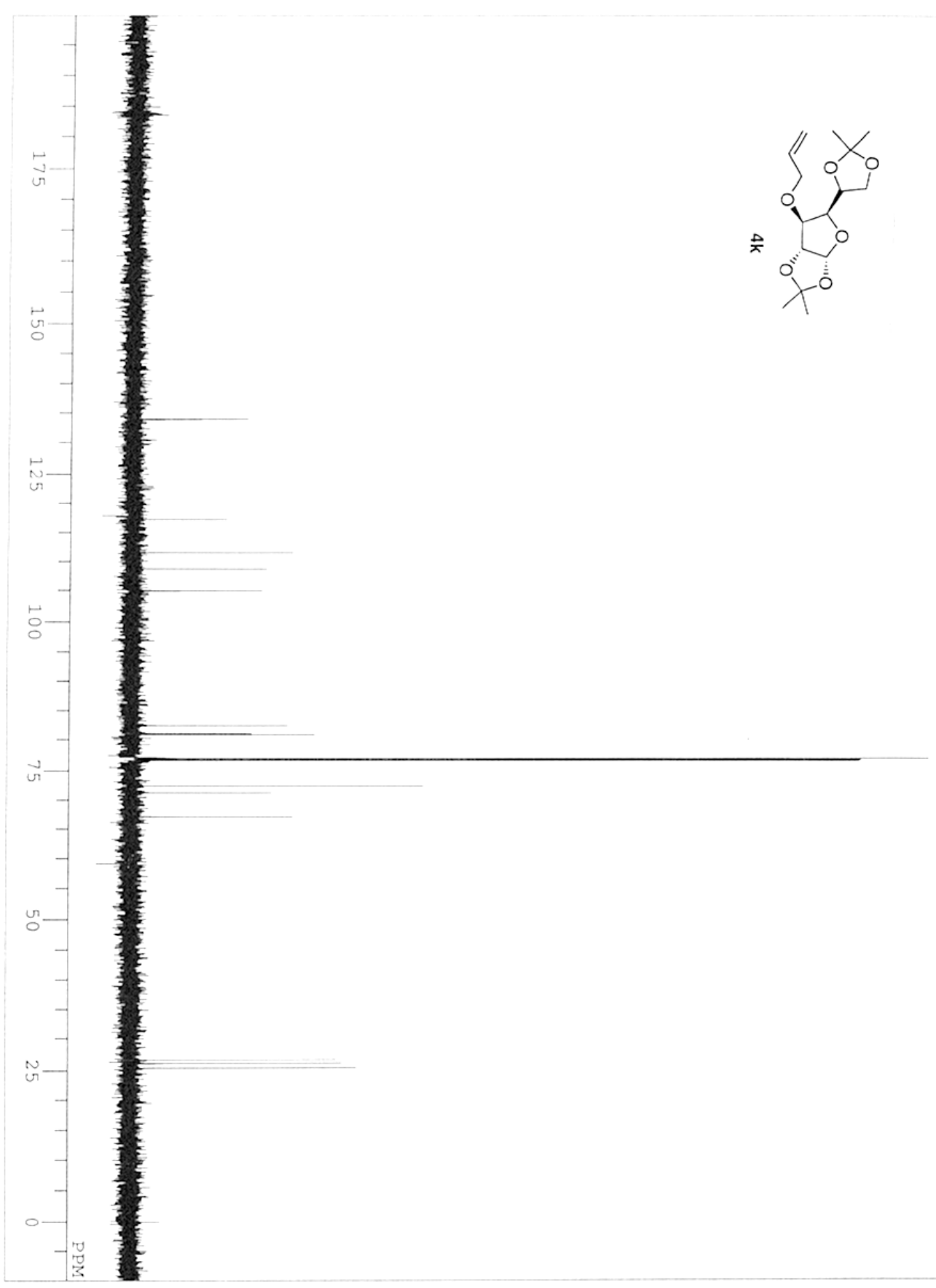

${ }^{13} \mathrm{C}$ NMR of $\mathbf{4 k}$

SI_2: page - 32 - 


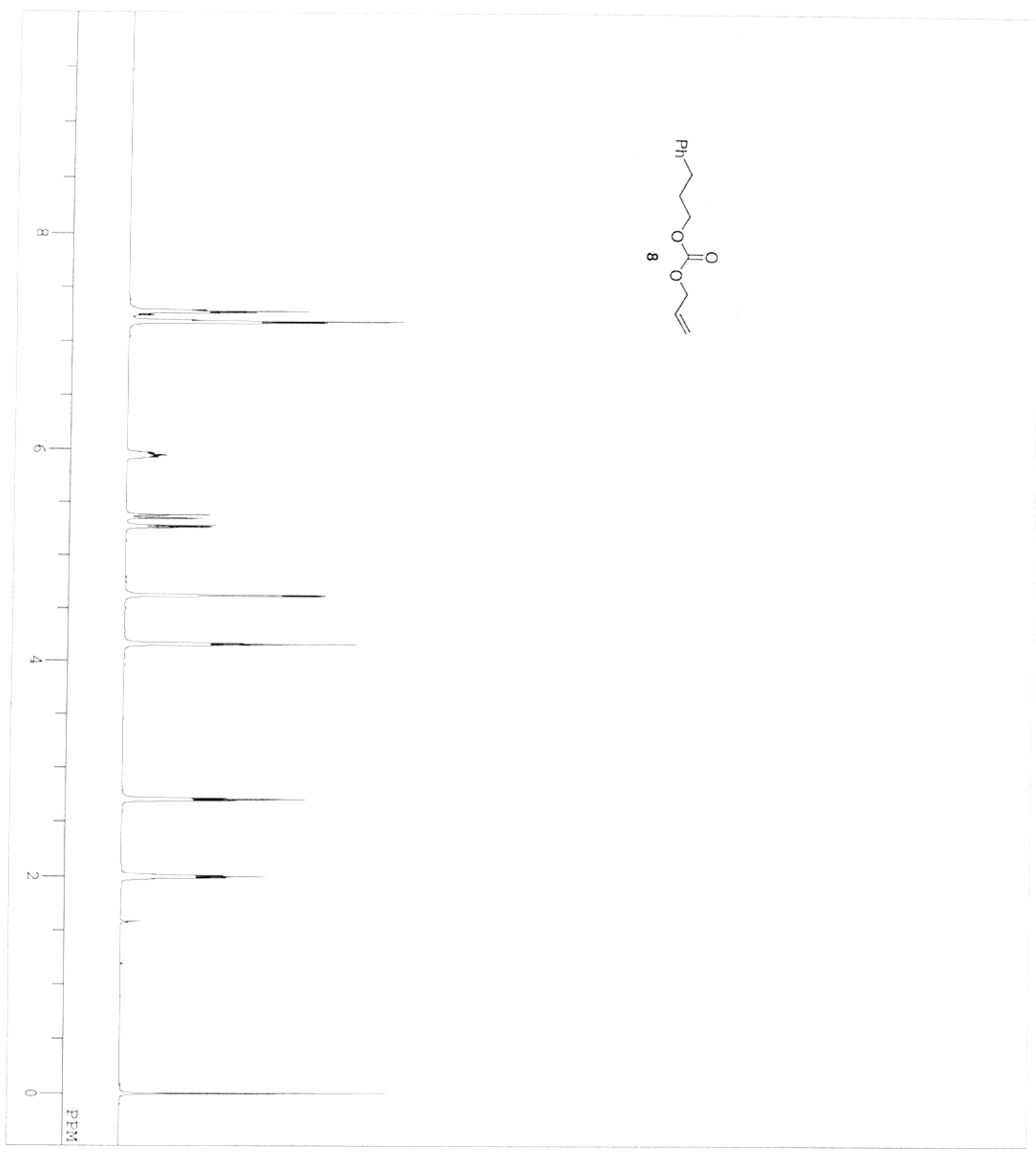

${ }^{1} \mathrm{H}$ NMR of 8

SI_2: page - 33 - 


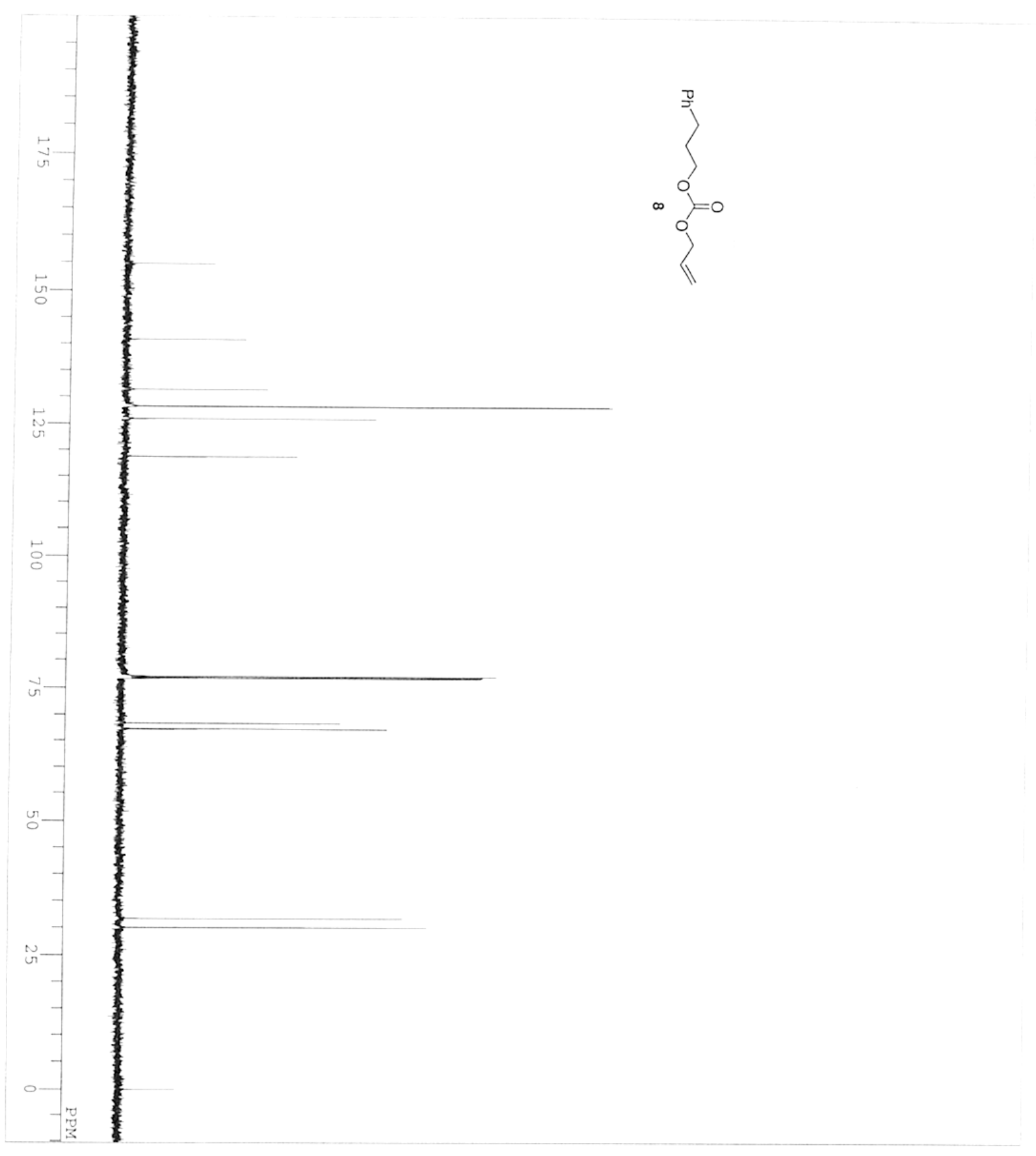

${ }^{13} \mathrm{C}$ NMR of 8

SI_2: page - 34 - 


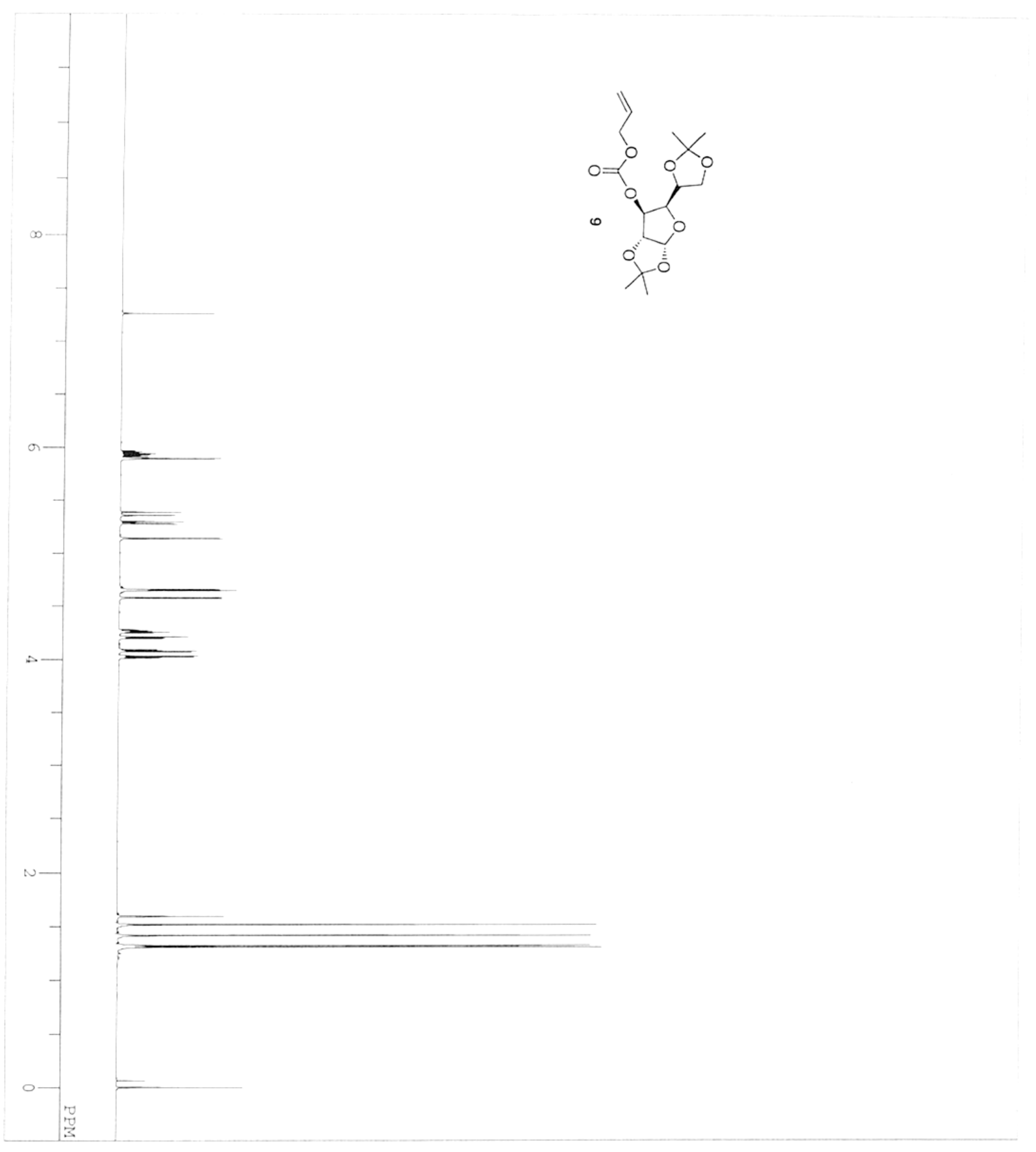

${ }^{1}$ H NMR of 9

SI_2: page - 35 - 


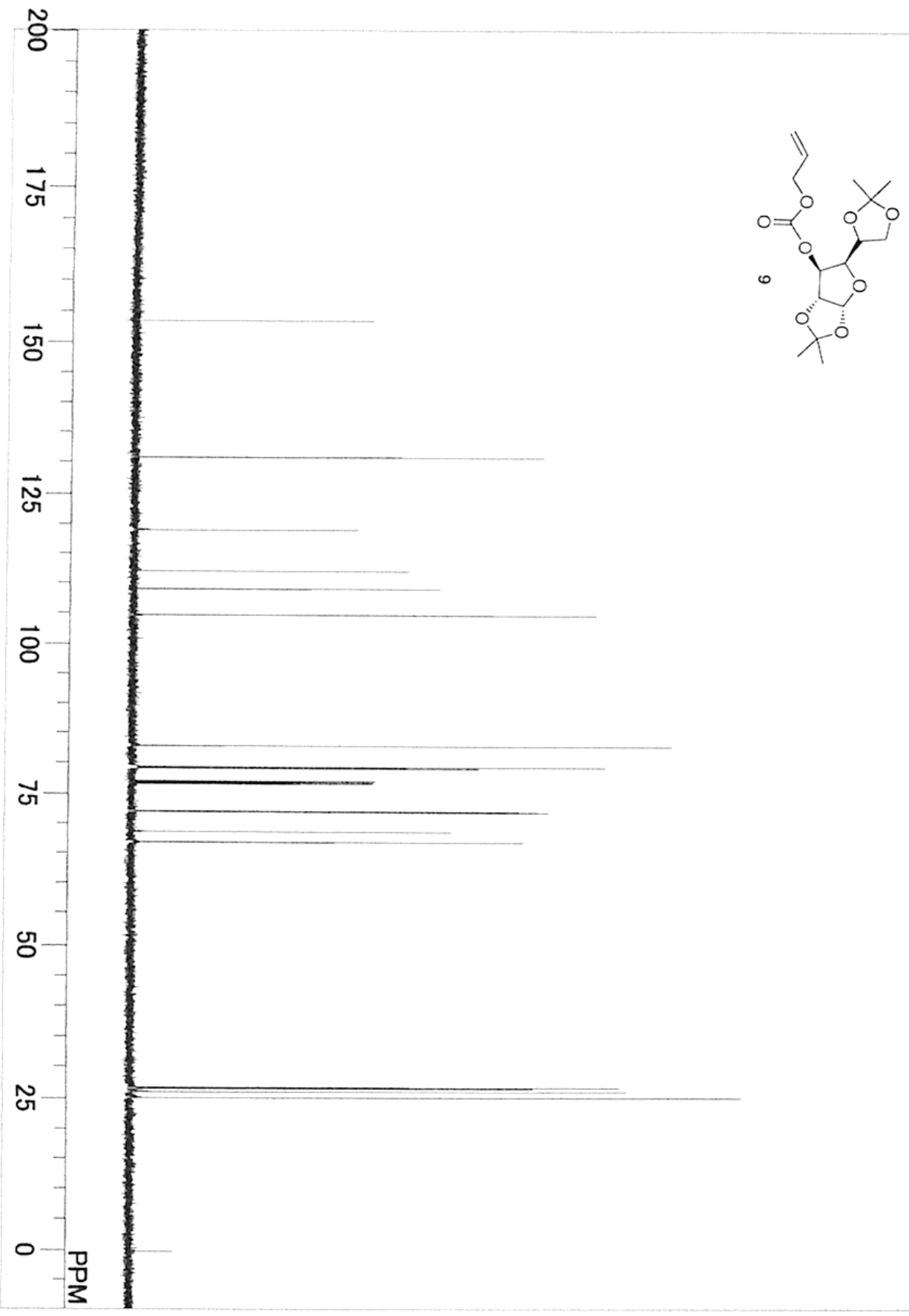

${ }^{13} \mathrm{C}$ NMR of 9

SI_2: page - 36 - 


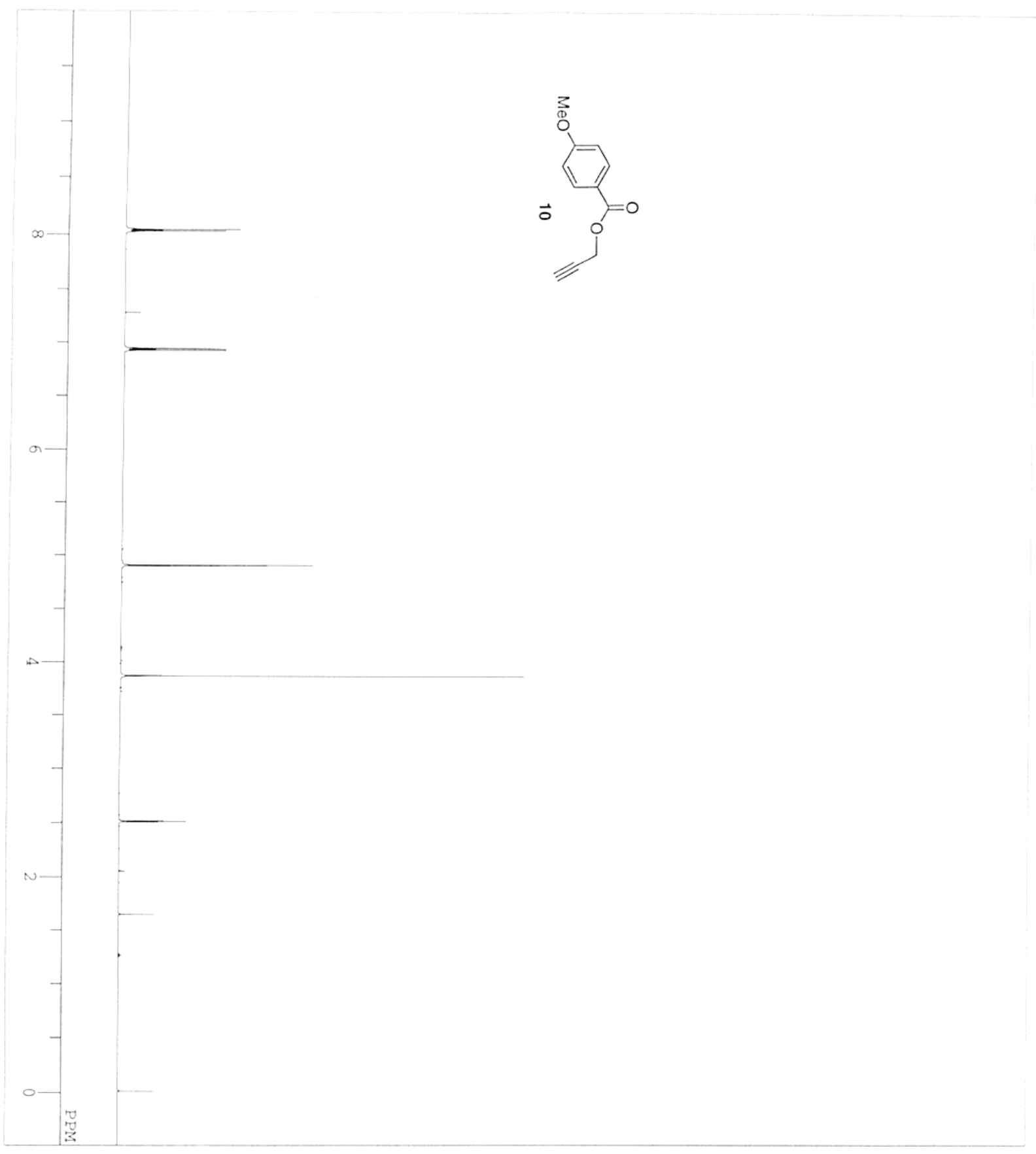

${ }^{1} \mathrm{H}$ NMR of $\mathbf{1 0}$

SI_2: page - 37 - 


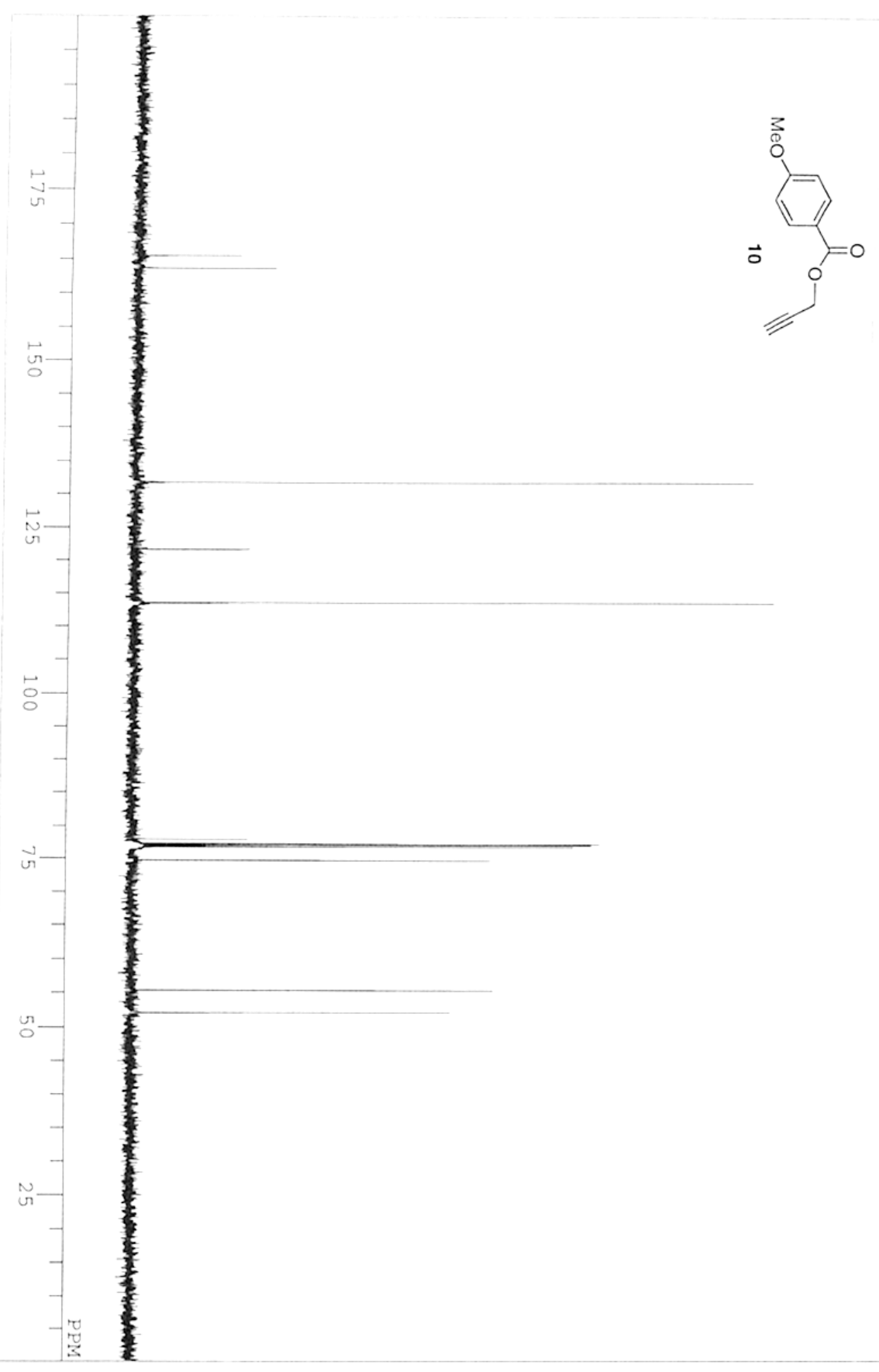

${ }^{13} \mathrm{C}$ NMR of 10

SI_2: page - 38 - 


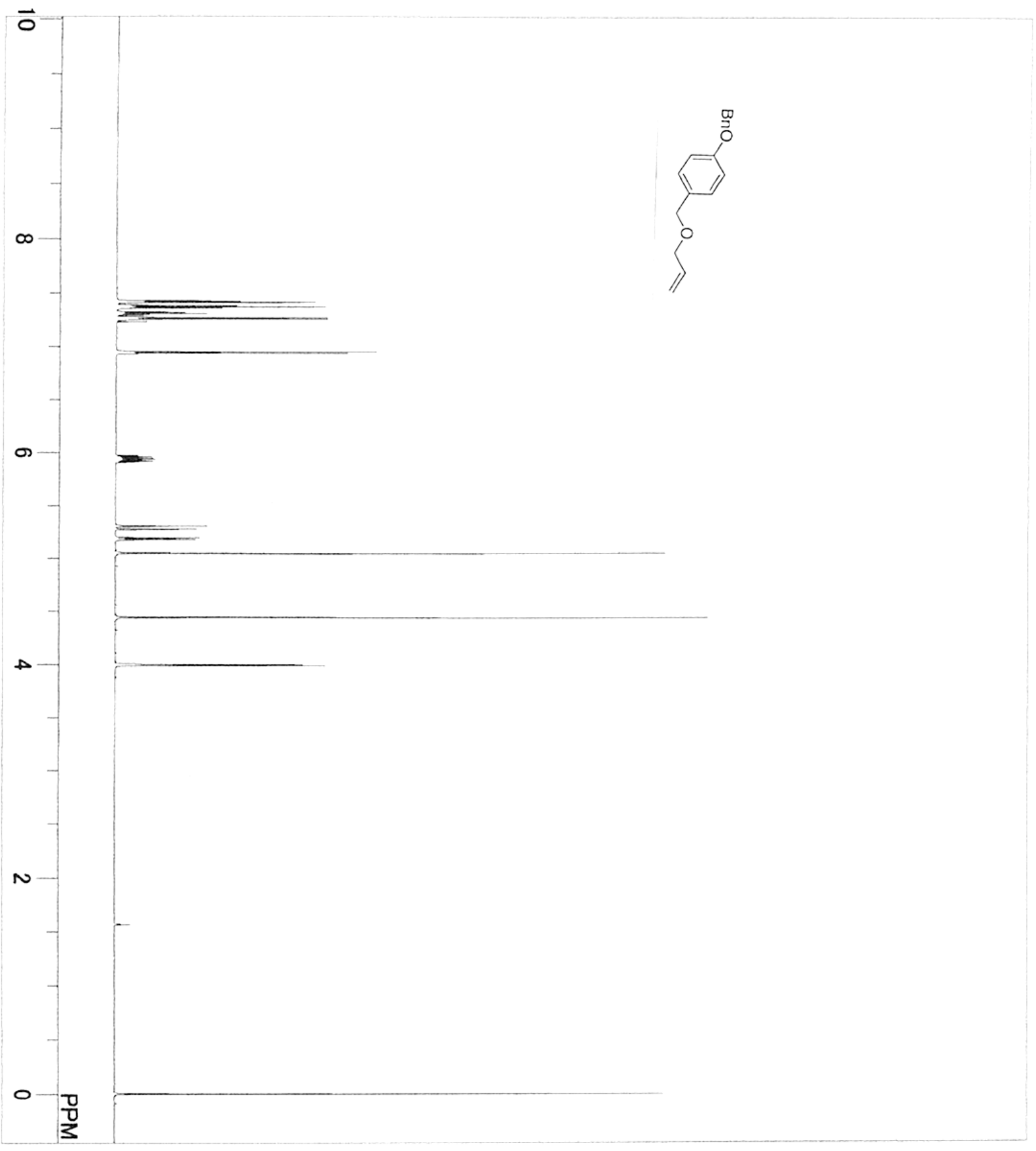

${ }^{1} \mathrm{H}$ NMR of 1-allyloxymethyl-4-benzyloxybenzene 


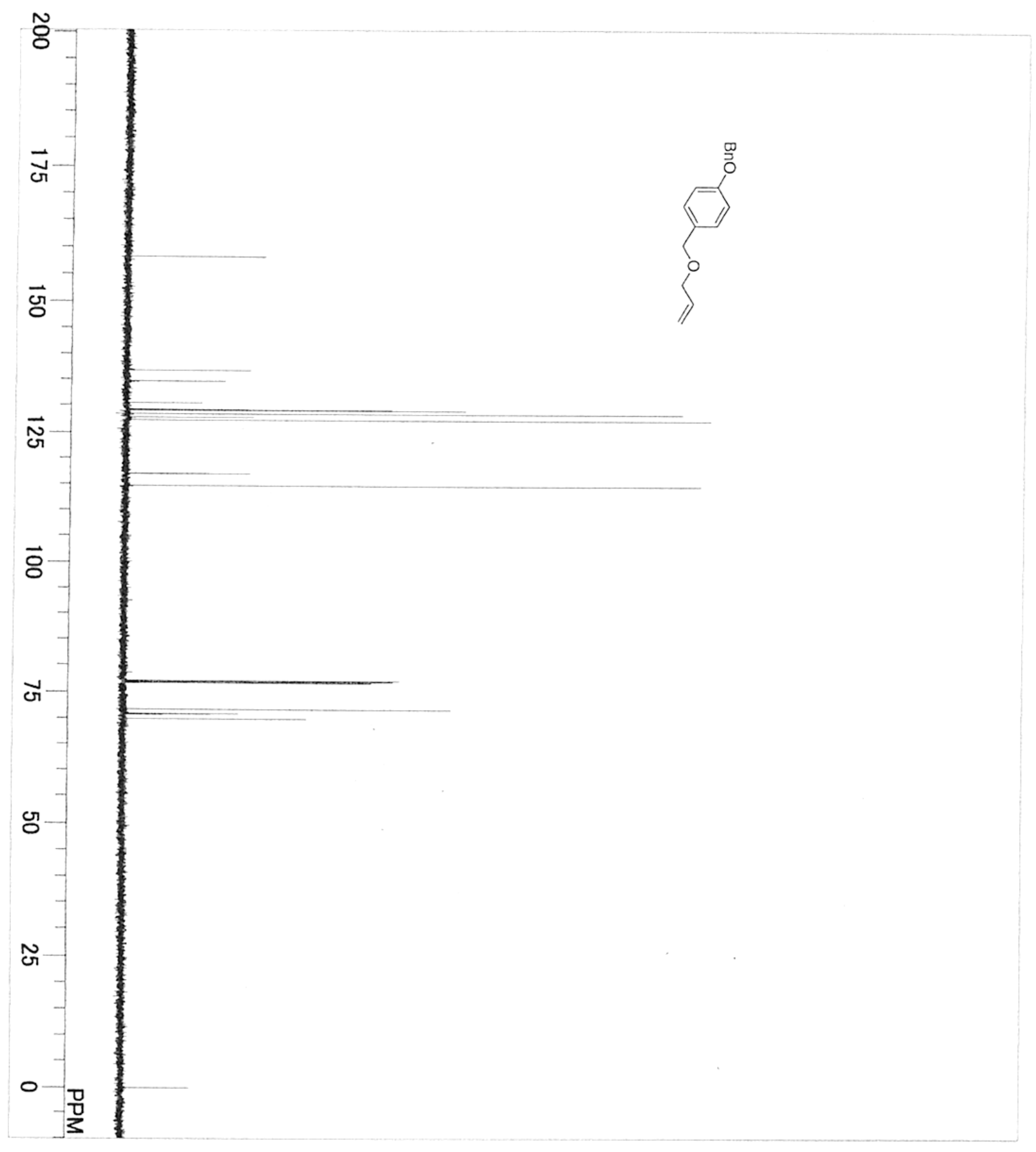

${ }^{13} \mathrm{C}$ NMR of 1-Allyloxymethyl-4-benzyloxybenzene 


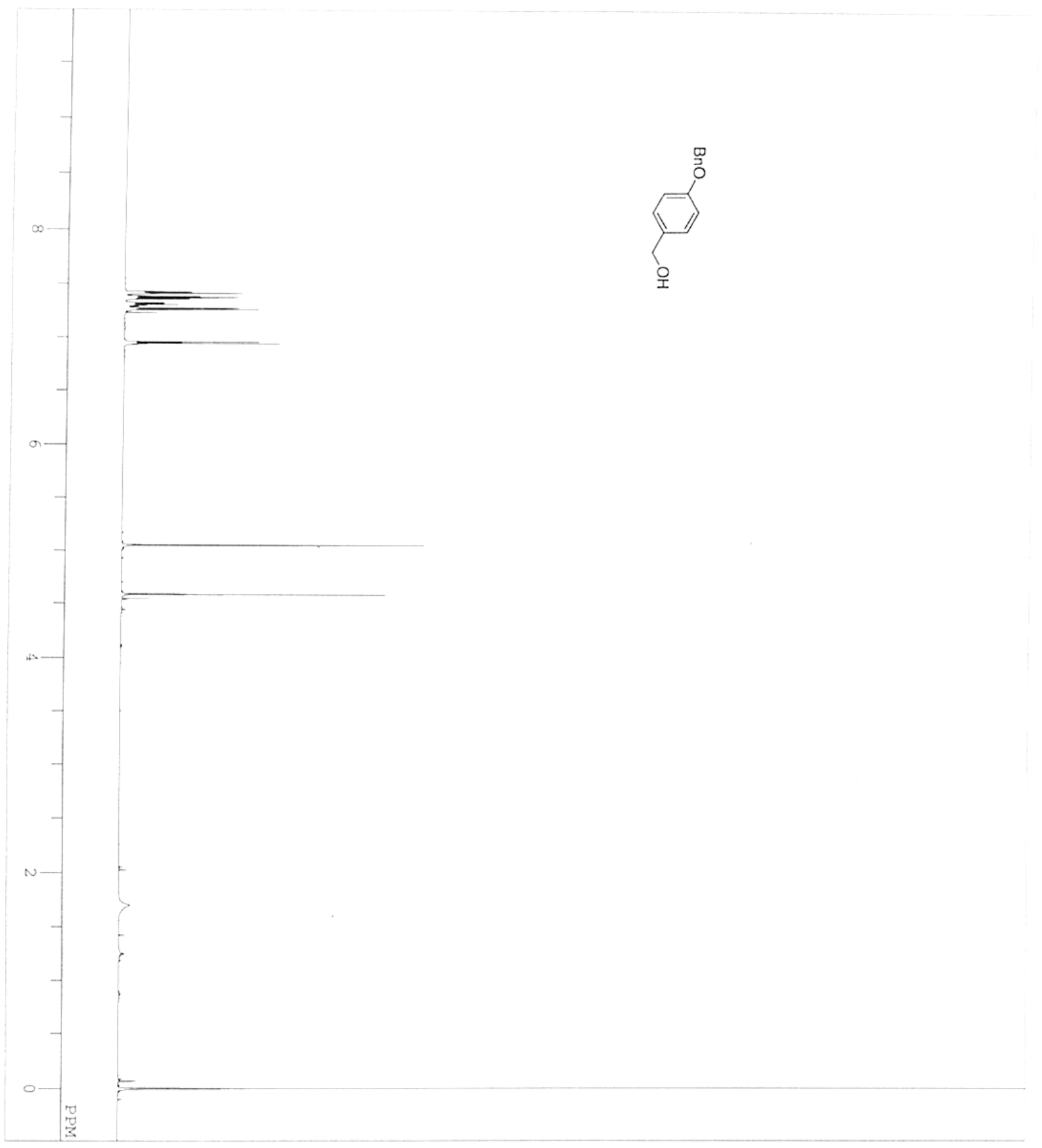

${ }^{1} \mathrm{H}$ NMR of (4-benzyloxyphenyl)-methanol 


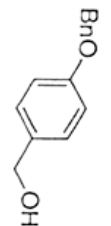

${ }^{13} \mathrm{C}$ NMR of (4-benzyloxyphenyl)-methanol 


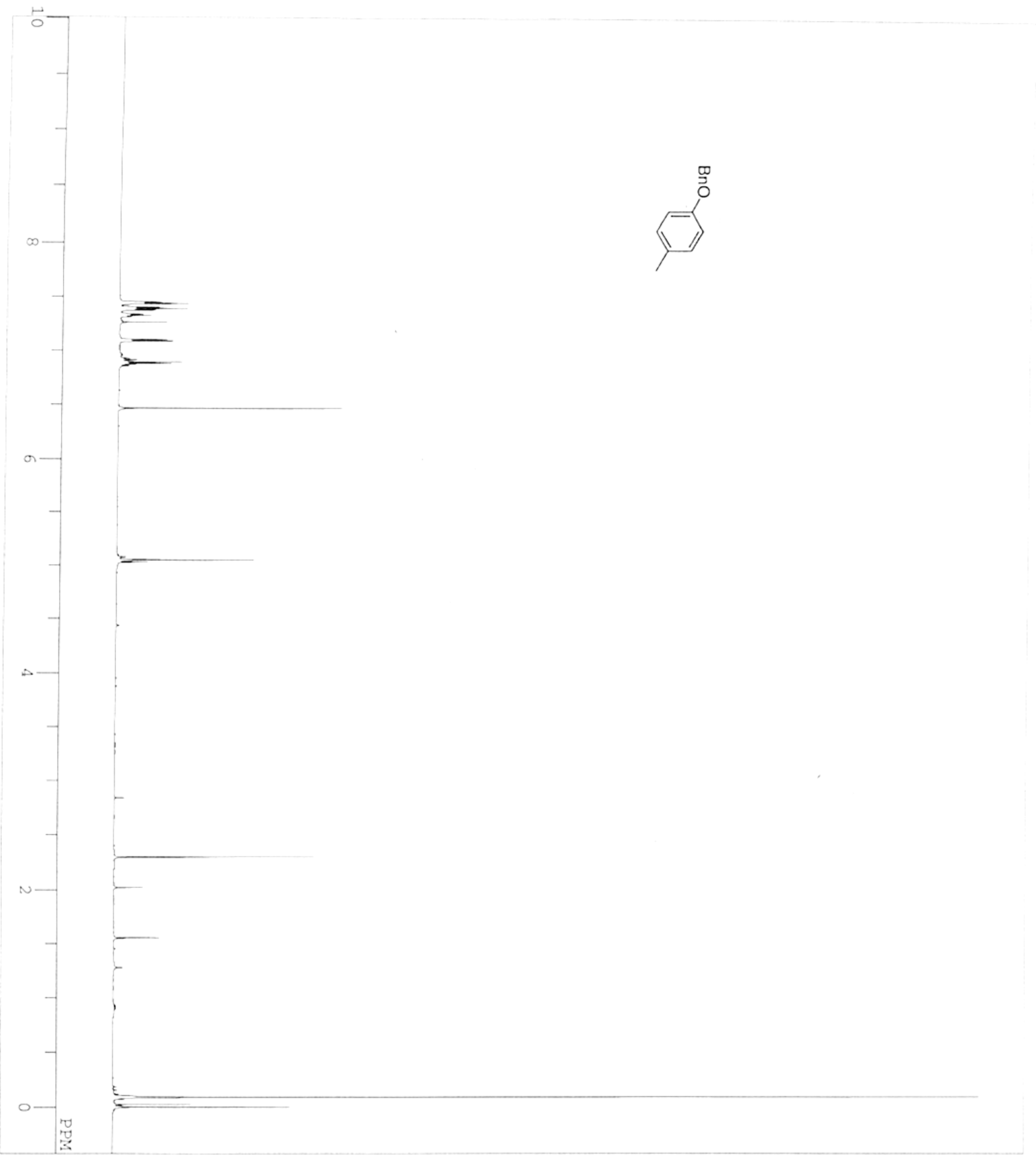

${ }^{1} \mathrm{H}$ NMR of 1-benzyloxy-4-methylbenzene 


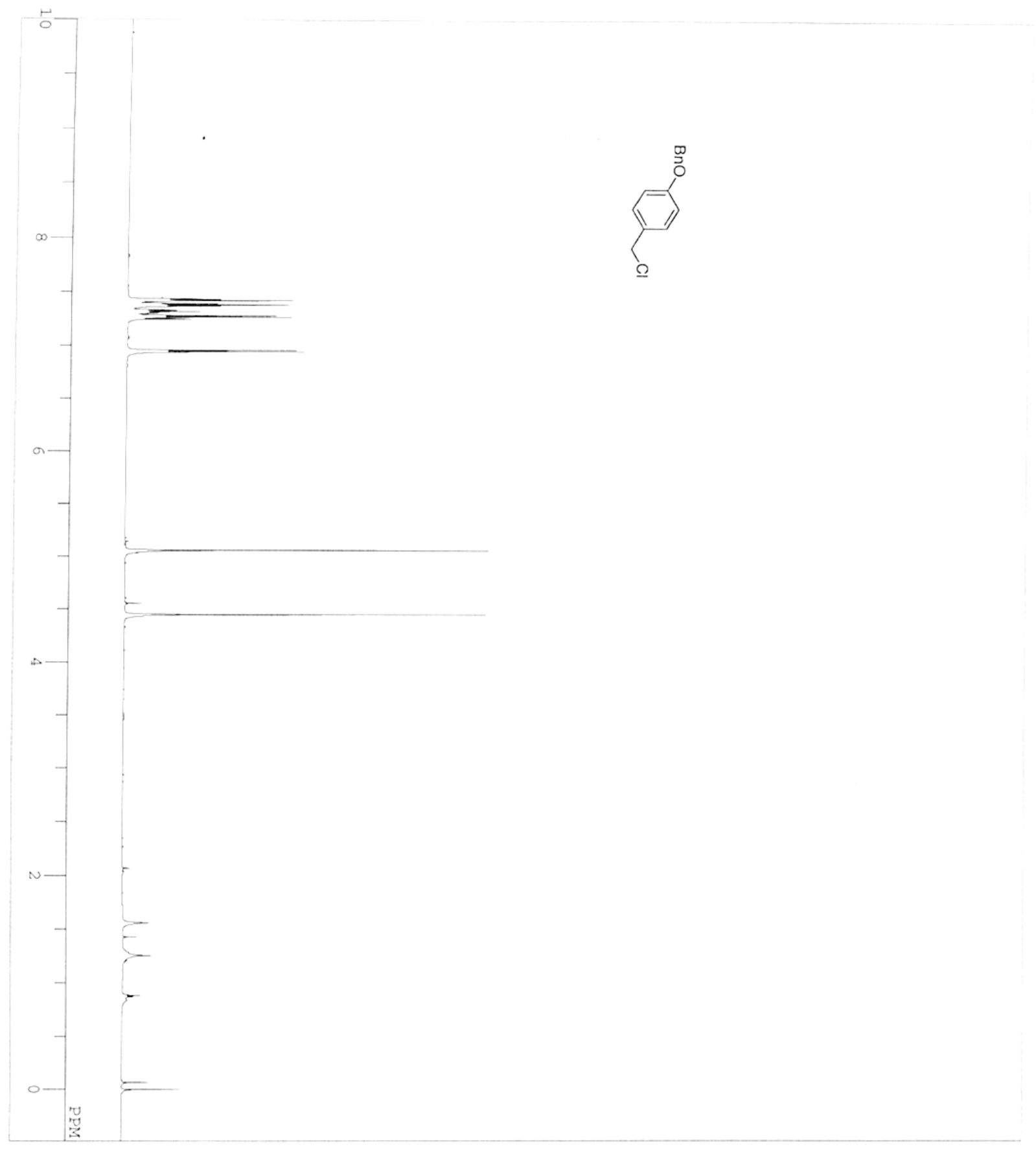

${ }^{1} \mathrm{H}$ NMR of 1-chloromethyl-4-benzyloxybenzene 


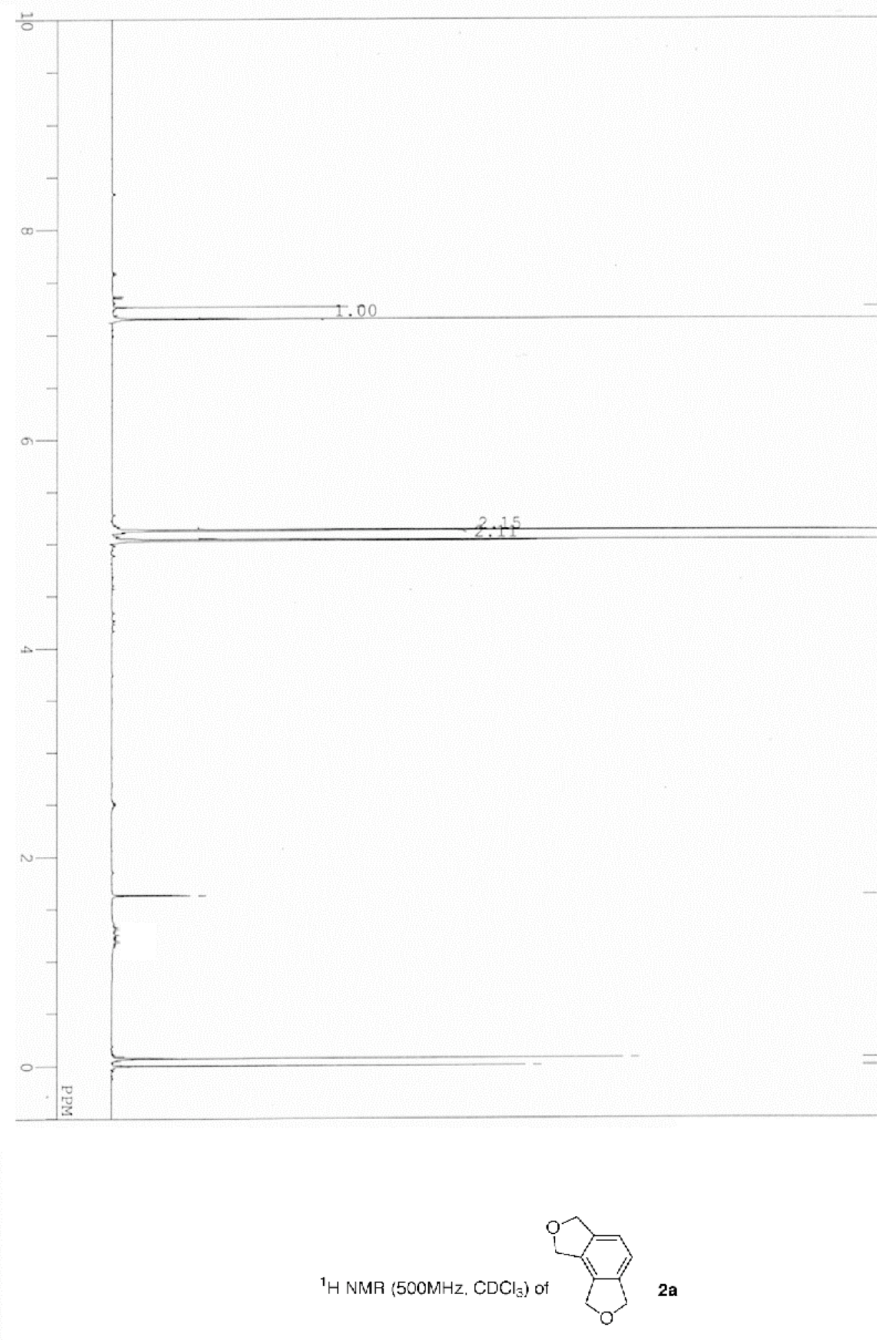

SI_2: page - 45 - 


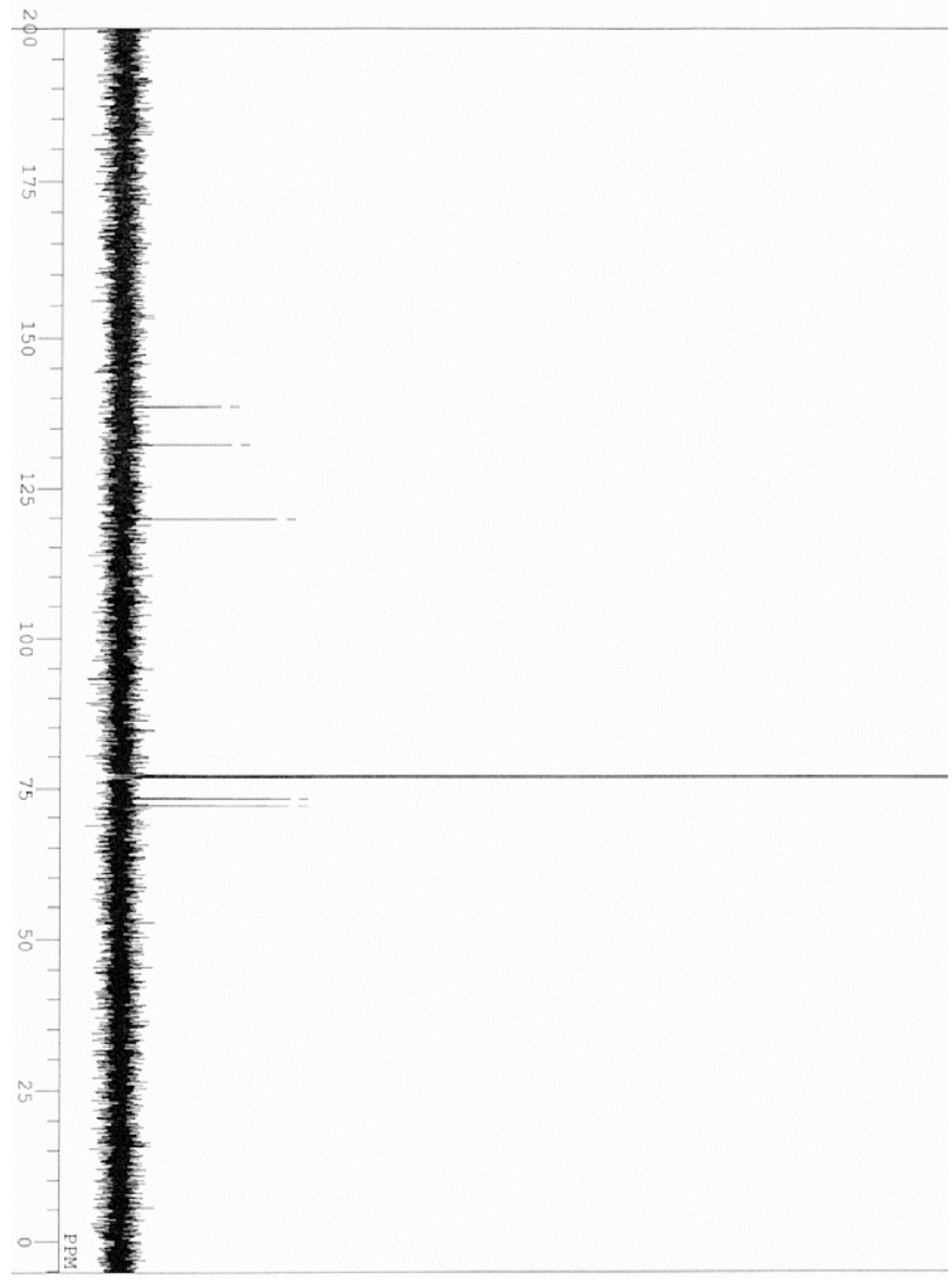

${ }^{13} \mathrm{C} \mathrm{NMR}\left(125 \mathrm{MHz}, \mathrm{CDCl}_{3}\right)$ of

SI_2: page - 46 - 


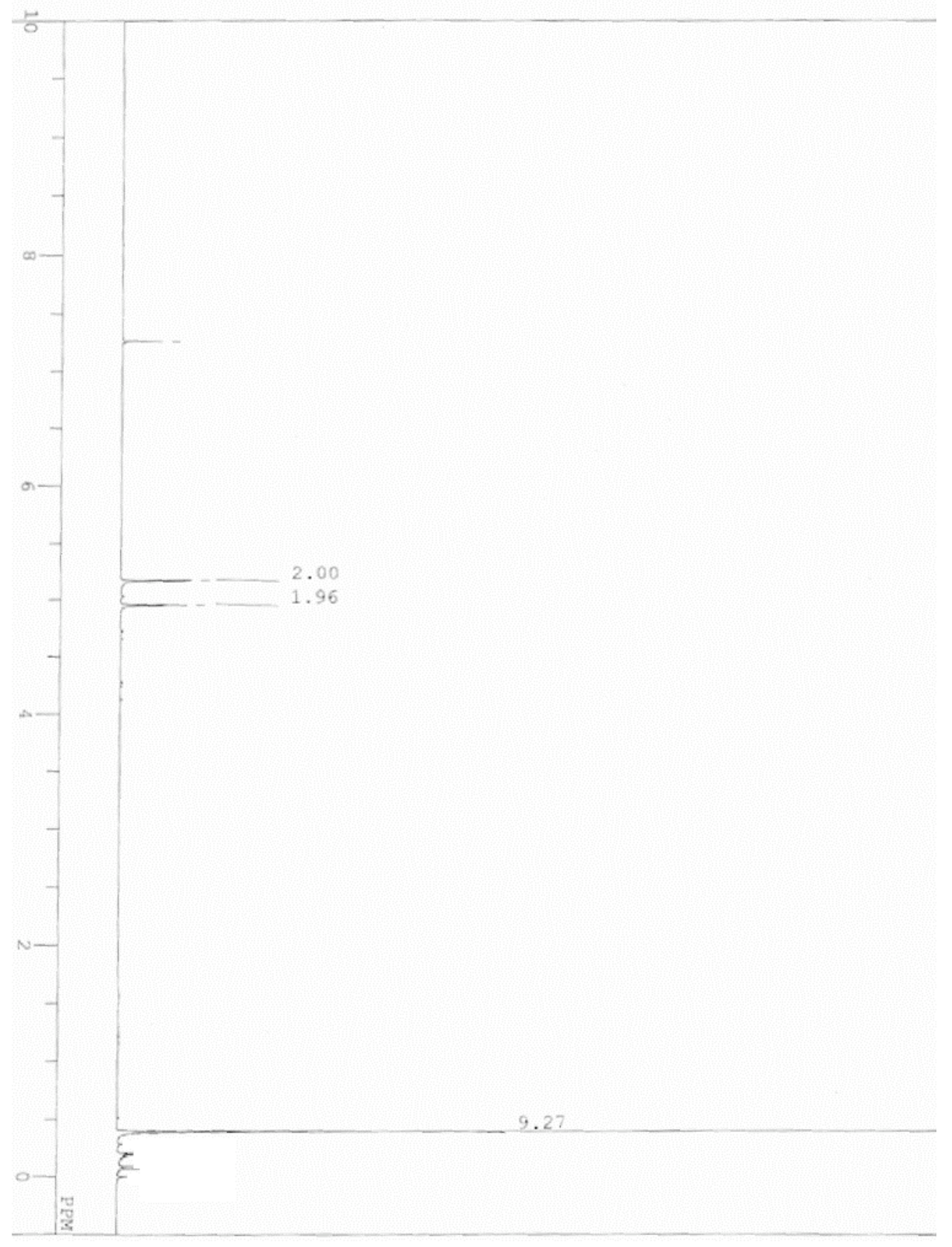

H NMR $\left(500 \mathrm{MHz}, \mathrm{CDCl}_{3}\right)$ of

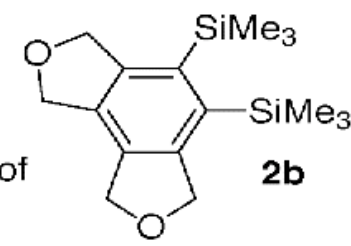

SI_2: page - 47 - 

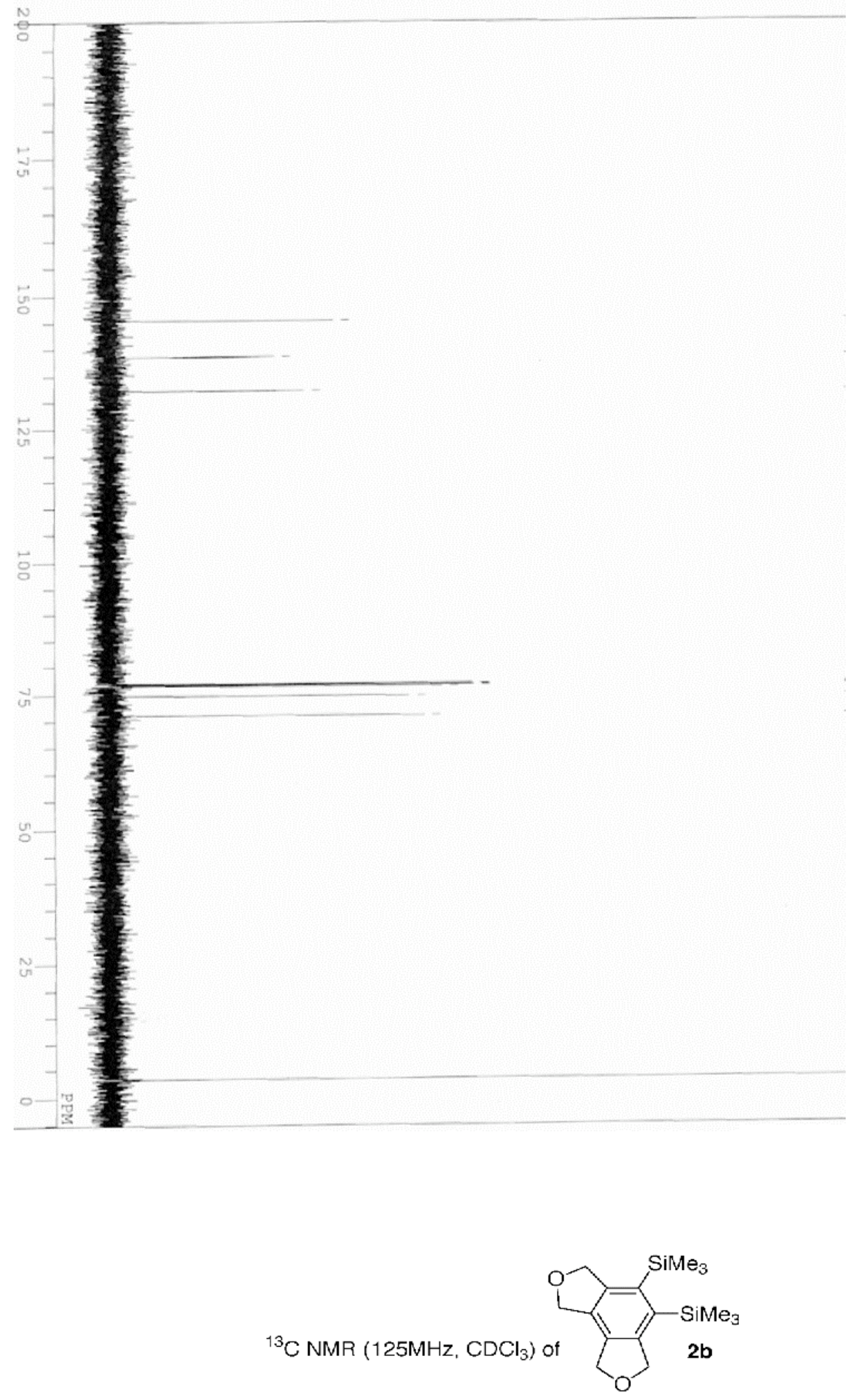

SI_2: page - 48 - 